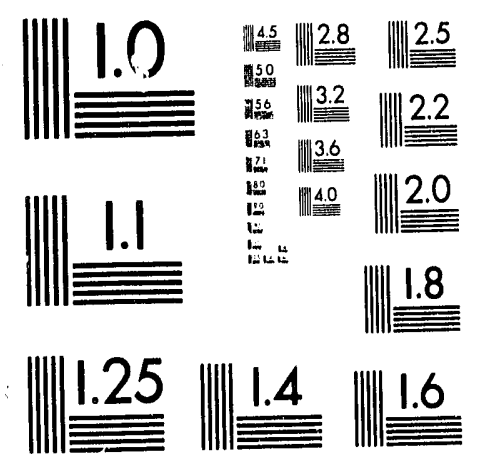



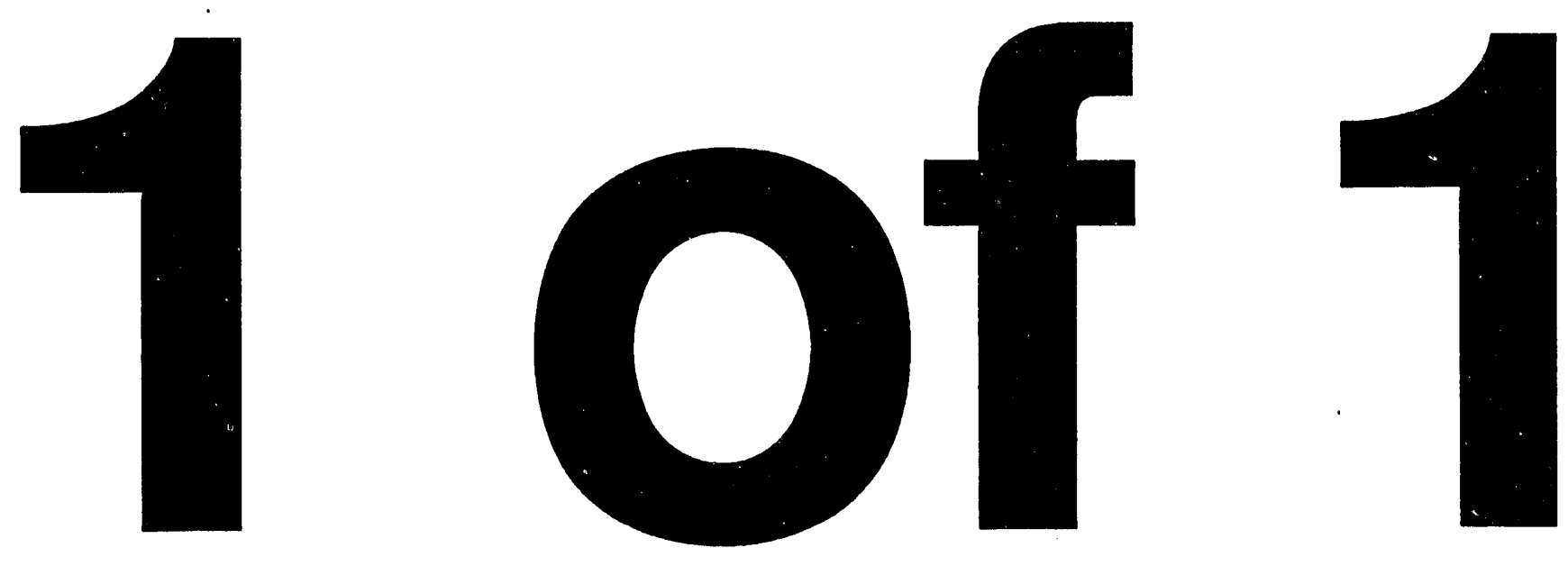
IS - 5092

Distribution Category UC 90a

ANNOTATED BIBLIOGRAPHY OF METHODS

FOR DETERMINING SULFUR AND FORMS OF SULFUR

IN COAL AND COAL-RELATED MATERIALS

Colin D. Chriswell, Glenn A. Norton, S. Suhail Akhtar, Warren E. Straszheim, and Richard Markuszewski

Fossil Energy Program

Ames Laboratory, U. S. Department of Energy,

Iowa State University

Ames, lowa 50011

Date Transmilted: January 1993

Prepared for the Pittsburgh Energy Technology Center,

U. S. Department of Energy under Contract W-7405-ENG-82

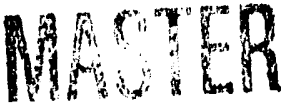




\section{NOTICE}

This report was prepared as an account of work sponsored by the United States Government. Neither the United States nor the United States Department of Energy, nor any of their employees, nor any of their contractors, subcontractors, or their employees, makes any warranty, expressed or implied, or assumes any legal liability or responsibility for the accuracy, completeness, or usefulness of any information, apparatus, product or process disclosed or represents that its used would not infringe on privately owned rights.

Available from:

Office of Scientific and Technical Information U. S. Department of Energy P. O. Box 62

Oak Ridge, Tennessee 37830 


\section{TABLE OF CONTENTS}

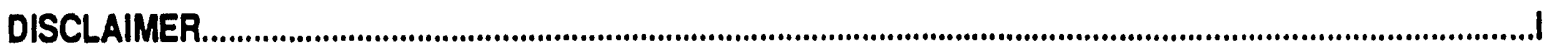

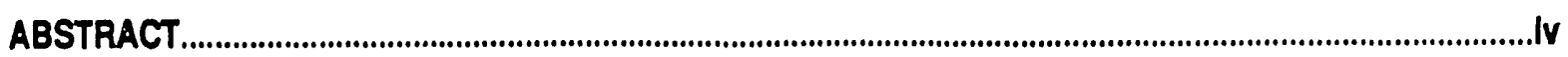

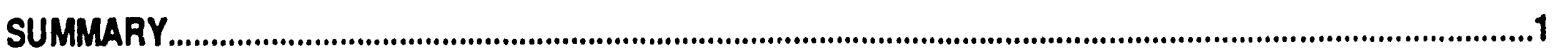

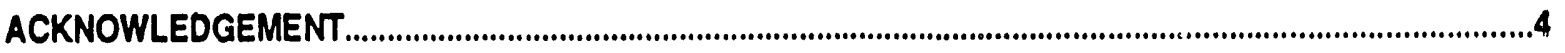

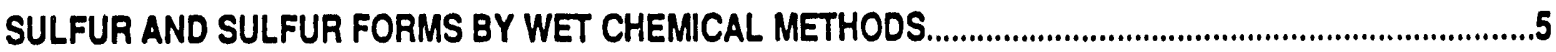

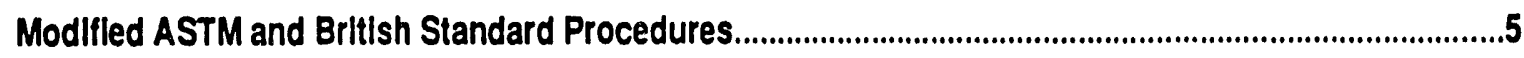

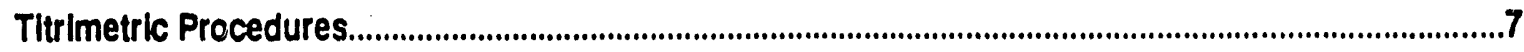

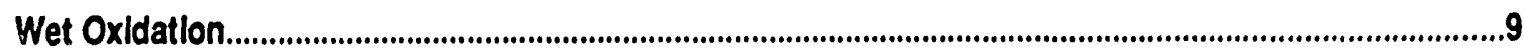

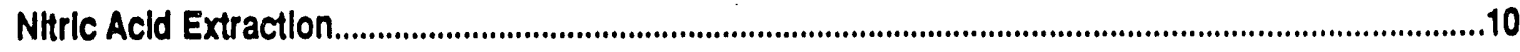

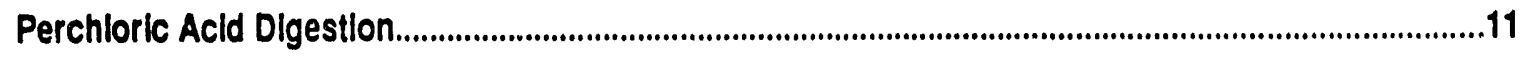

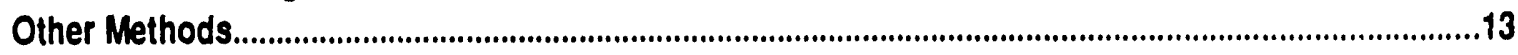

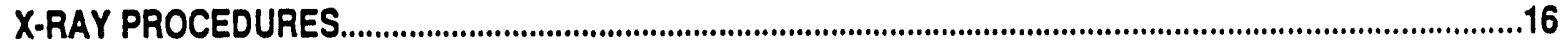

$X$-Ray Photoelectron Spectroscopy (XPS)/Electron Spectroscopy for

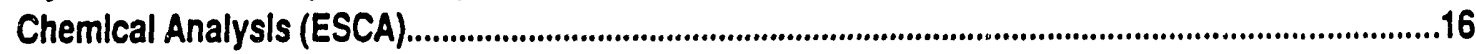

Electron Microprobe, SEM-EDX and Automated Image Analysis Technlques........................................19

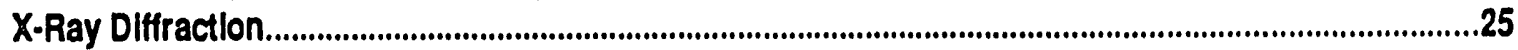

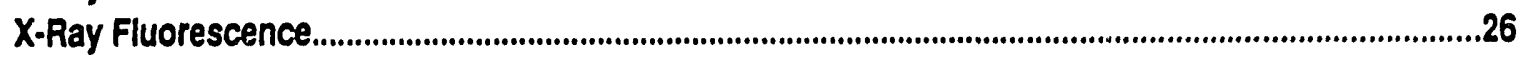

Gamma Ray Spectroscopy.............................................................................................................29

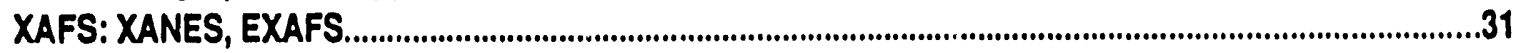

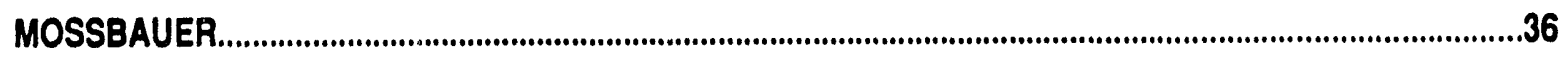

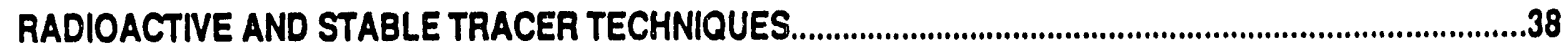

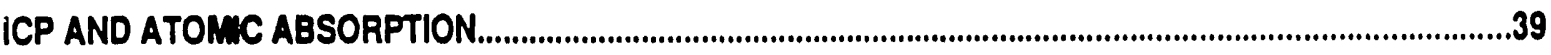

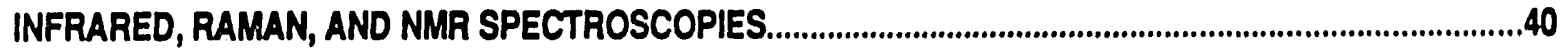

Infrared and Raman Spectroscoples..................................................................................................40

Nuclear Magnetlc Resonance Spectroscopy...............................................................................................41

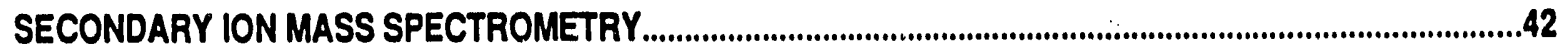




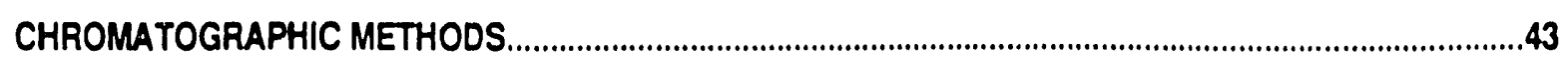

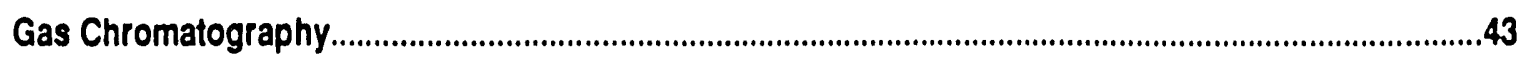

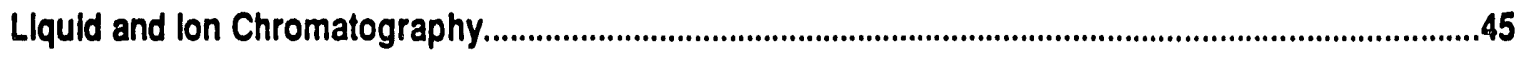

DETERMINATION OF SULFUR BY METHODS BASED UPON COMBUSTION AND PYROLYSIS.................47

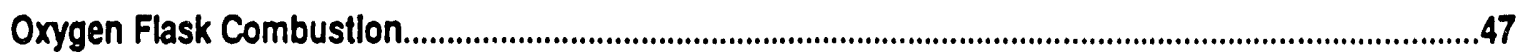

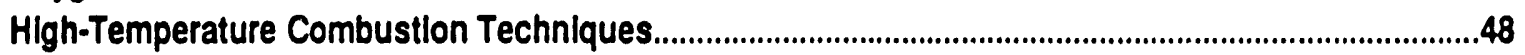

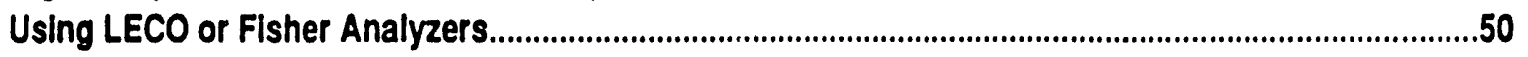

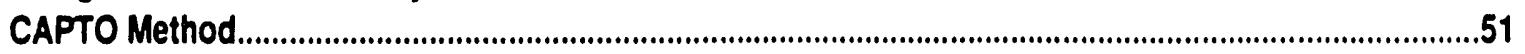

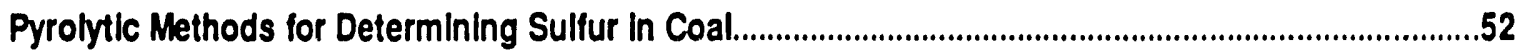

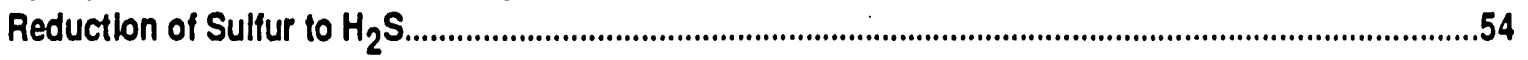

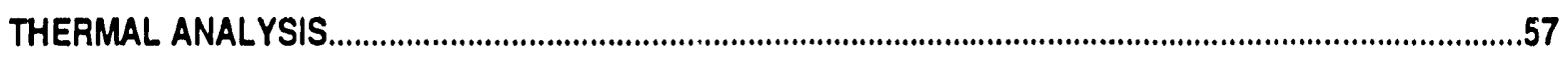

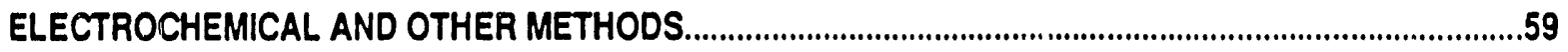

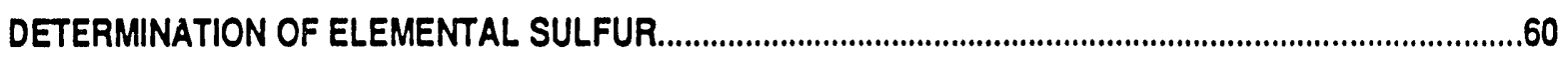

DETERMINATION OF SULFIDES, SULFITES, AND OTHER REDUCED SULFUR COMPOUNDS..................62

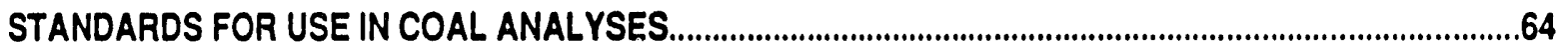

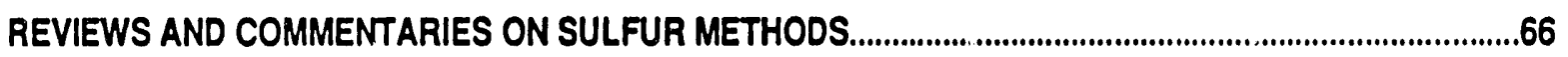

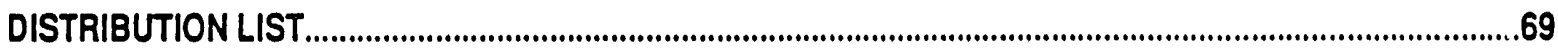




\section{ABSTRACT}

Over 400 published papers, presentations at scientific meetings, and reports relating to the determination of sulfur and sulfur forms in coal and coal-related materials have been accumulated, classified, and an evaluation made of their content. 


\title{
ANNOTATED BIBLIOGRAPHY OF METHODS FOR DETERMINING SULFUR AND FORMS OF SULFUR IN COAL AND COAL-RELATED MATERIALS
}

\author{
Colin D. Chriswell, Glenn A. Norton, S. Suhaii Akhtar, \\ Warren Straszheim, and Richard Markuszewski
}

\section{SUMMARY}

\section{Introduction}

Effective, practical, standard methods have been developed, validated, and are widely used for determining the total sulfur content and the major forms of sulfur in coal. Despite the existence of these standard methods, a great deal of effort is being devoted to the development of new procedures for determining sulfur and forms of sulfur in coal and coal-related materials. A total of over 400 papers describing new or modified procedures for determining sulfur in coal have been located in the literature; including twenty-five such papers published in 1991 alone.

In part, the research on new methods for determining sulfur forms in coal is directed towards simplifying or reducing the cost of existing methods. Much of the research is also aimed at developing procedures applicable to a wider range of coals and coal-like materials. Another area of intense research the development of procedures to yield more information about the nature of sulfur in coal; of particular interest is the forms of organic sulfur in coal.

\section{Objectives of the Present Work}

The primary goal of the present work was to compile a bibliography of all existing procedures currently used or applicable for the determination of sulfur or the forms of sulfur in coal and coal-related materials. A second goal of this work was to classify those methods in a usable manner. And, a final objective was to perform a preliminary evaluation of the applicability of the methods.

\section{Bibliography of Methods}

In compiling the bibliography of methods, an effort was made to include all procedures which were intended to be used in determining sulfur or forms of sulfur in coal or coal-related materials. In addition, other papers were included which appeared 
to have applicability to such analyses, but were not intended for that purpose. One example of the latter type of papers are methods proposed for chemically cleaning coal that appear to selectively remove only certain forms of sulfur from coal. Such methods might be modified for use in determining forms of sulfur in coal. Also included were methods for determining forms of sulfur in streams similar to those that might arise from the processing of coal, but have not been applied to coal-derived materials. Examples of these include several papers describing methods for determining inorganic sulfur containing compounds in aqueous solutions.

Over a thousand published papers dealing with some facet of sulfur in coal or other matrices were considered for inclusion in this bibliography, and over 400 were selected as being applicable to analysis.

\section{Classification of Methods}

Two different approaches were used in classifying methods for determination of sulfur. Methods were classified primarily based upon the technique or instrumentation used. For example, all x-ray-based methods were placed in a separate classification. This choice of a method of classification was based upon the expectation that users will only apply those analytical methods that they possess the equipment and expertise to perform. In addition, some methods were classified based upon the forms of sulfur to which they were applicable. For example, methods for determining elemental sulfur were placed in a separate classification.

A summary of the classification of the methods is given in Table 1. As can be seen, wet chemical, $x$-ray, and combustion and pyrolysis methods dominate the listings. Within this table, papers were also classified by their dates of publication to give some indication of the current interest the procedure described. As might be expected, development of $x$ ray methods is still an area of active research. But, it is interesting to note that a great deal of effort is also currently being devoted to more the more classical wet chemical and combustion areas of analysis. 
Table 1. Summary of Methods for the Determination of Sulfur and Forms of Sulfur in Coal and Coal Related Materials

\section{Type of Method}

Wet Chemical

$X$-Ray Procedures

Mossbauer Spectroscopy

Tracer Techniques

ICP and Atomic Absorption

Infrared, Raman and NMR

Secondary lon MS

Chromatographic Methods

Combustion and Pyrolysis

Thermal Analysis

Electrochemical

Elemental Sulfur

Reduced Sulfur Compounds

Standards

Reviews and Commentaries
Number of Citations

\begin{tabular}{rccc}
\hline Total & $\frac{1991-1992}{80}$ & $\frac{1986-1990}{4}$ & $\frac{1981-1985}{10}$ \\
132 & 13 & 47 & 42 \\
17 & 1 & 3 & 3 \\
7 & 0 & 3 & 4 \\
3 & 0 & 2 & 1 \\
9 & 0 & 2 & 6 \\
3 & 0 & 2 & 1 \\
25 & 2 & 7 & 11 \\
64 & 4 & 16 & 14 \\
10 & 0 & 1 & 9 \\
5 & 0 & 4 & 1 \\
16 & 0 & 7 & 3 \\
20 & 0 & 2 & 4 \\
7 & 0 & 4 & 3 \\
26 & 0 & 6 & 7
\end{tabular}

\section{Evaluation of Methods}

The primary tool for evaluation of analytical methods was the data and descriptions contained in the published papers themselves. An effort was made to summarize the authors' descriptions of methods and results. Based upon our own experience, an effort was made to provide additional insight into the applicability of methods. In almost all cases, the papers evaluated describe methods developed to solve specific problems or demonstrate capabilities, and in almost all cases, at least some success was achieved.

One area of research that does invite comparisons among methods is the determination of the forms of organic sulfur in coal. At the present, there are at least five different approaches being pursued. Of these approaches, the examination of the x-ray 
absorption fine structure appears to provide the greatest amount of information, but this technique requires the use of a high-intensity $x$-ray source that can only provided by $a$ synchrotron. The procedures based upon step-wise oxidation with perchloric acid require the least expensive equipment and do differentiate among different organic sulfur forms, but the use of highly-trained is required during any work with perchloric acid. Methods based upon programmed reduction of sulfur forms to hydrogen sulfide appear to provide the least information about the forms of organic sulfur in coal. Recent work with flash pyrolysis methods shows considerable promise as a usable technique for differentiating among organic sulfur forms in coal. Overall, the so-called CAPTO (controlled atmosphere programmed temperature oxidation) may represent the best compromise in that it appears to provide usable data on organic sulfur forms in coal, is usable by trained analysts, and makes use of equipment that is accessible.

With all analytical methods good standards are required. Developing standards for determining the forms of organic sulfur in coal appears to be a significant unmet challenge.

\section{ACKNOWLEDGEMENT}

Ames Laboratory is operated by lowa State University for the U. S. Department of Energy under contract No. W-7405-ENG-82. This work was supported by the Assistant Secretary for Fossil Energy through the Pittsburgh Energy Technology Center with Richard Read serving as project monitor.

The assistance of Robert Dawson, Rachel Peters, Victor Jewell, Xiang Zhou, and William Buttermore in preparing and editing this bibliography is greatly appreciated. 
$-5-$

\section{SULFUR AND SULFUR FORMS BY WET CHEMICAL METHODS}

\section{Modified ASTM and British Standard Procedures}

ASTM and British Standard Methods for the determination of total, pyritic, sulfatic, and organic sulfur in coal were designed to be used on normal, untreated coals. Most modifications of these methods have been proposed in order that the standard methods can be applied to abnormal coals, treated coals, and coal-like materials $(2,4-6,8,12,13,16-20,22)$. Other modifications have been proposed for reducing the time or labor involved in performing the determinations $(3,14,21)$. Alterations in the turbidimetric procedures for the analysis of sulfate have also been proposed $(1,7,10,11)$. Chakrabartty has discussed the problems associated with applying standard methods to some low-sulfur coals (9). Kuhn (15) proposed to convert isolated sulfur to sulfide using lithium aluminum hydride as a reductant. The su'fide is then determined by precipitation of cadmium sulfide.

1. AHMED, S. M., WHALLEY, B. J. P., "VOLUMETRIC FINISH FOR ESCHKA ANALYSES USING ARSENAZO III," FUEL, 51(4), PP. 334-335, 1972.

2. ALVIN, J, MCCARTHY, D., POYNTON, H., "P. IODIFICATIONS OF STANDARD METHODS FOR COAL ANALYSIS OF SULFUR AND NITROGEN DETERMINATIONS IN OIL SHALES," ANALYST, 109 (2), PP. 131-133, 1984.

3. BAUR, P., "SPEED UP YOUR LABORATORY SULFUR-IN-COAL ANALYSIS," POWER, 126(7), PP. 73-75, 1982.

4. BIALOBOK, S. J., SECKEL, J. A., "THE EFFECTS OF SOME OXIDANTS ON THE ARTIFICIAL OXIDATION OF COAL," PITTSBURGH CONFERENCE ON ANALYTICAL CHEMISTRY AND APPLIED SPECTROSCOPY, PAPER N0. 465, 1976.

5. BUDGE, C. F., MACKNIGHT, F. J., "FORMS OF SULPHUR IN NEW ZEALAND COALS," NEW ZEALAND JOURNAL OF SCIENCE, 19, PP. 237-241, 1976.

6. BURNS, M. S., "DETERMINATION OF PYRITIC SULPHUR IN AUSTRALIAN COALS," FUEL, 49(2), PP. 126-133, 1970.

7. BYKOVA, A. P., OKHAPKINA, L. L., "DETERMINATION OF SULFATE-SULFUR IN COALS BYA COMPLEXOMETRIC METHOD," IZV. NAUCH.- ISSLED. INST. NEFTL- UGLEKHIM, (BULLETIN OF THE SCIENTIFIC RESEARCH INSTITUTE AT IRKUTSK UNIVERSITY), 8, PP. 14-19, 1966. 
8. CHAKRABARTI, J. N., "ANALYTICAL PROCEDURES FOR SULFUR IN COAL DESULFURIZATION PRODUCTS," ANALYTICAL METHODS FOR COAL AND COAL PRODUCTS, VOLUME I, C. KARR, JR., ACADEMIC PRESS, NY, PP. 279-322, 1978.

9. CHAKRABARTTY, S. K., IACCHELLI, A., THE DILEMMA OF ESTIMATING FORMS OF SULFUR IN LOW-SULFUR LOW RANK COALS, " CANADIAN JOURNAL OF CHEMISTRY, 64, PP. 861$864,1986$.

10. ELENKOVA, N. G., TSONEVA, R. A., NEDELCHEVA, T. K., "NEW TURBIDIME TRIC METHOD FOR DETERMINATION OF SULPHATE," TALANTA, 27, PP. 67-68, 1980.

11. FERRUS, R., TORRADES, F., "LIMIT OF DETECTION IN BARIUM SULPHATE GRAVIMETRY FOR WATER ANALYSIS," ANALYST, 110, PP. 403-406, 1985.

12. GLADFELTER, W. L., DICKERHOOF, D. W., "DETERMINATION OF SULPHUR FORMS IN HYDRODESULPHURIZED COAL," FUEL, 55(4), PP. 355-357, 1976.

13. GRAY, R. J., SCHAPIRO, N., COE, G. D., "DISTRIBUTION AND FORMS OF SULFUR IN A HIGH VOLATILE PITTSBURGH SEAM COAL," TRANSACTIONS, SOCIETY OF MINING ENGINEERS, PP. 113-120, 1963.

14. ISHIBASHI, Y., FUKUMOTO, K., MAEDA, K., OGAWA, A., GOTO, K., ISHI, T., "FULLY AUTOMATIC APPARATUS FOR PROXIMATE ANALYSIS AND TOTAL SULFUR ANALYSIS OF COAL AND COKE, ${ }^{n}$ JOURNAL OF IRON AND STEEL, PP. 387-93, 1985.

15. KUHN, J. K., KOHIENBERGER, L. B., SHIMP, N. F., "COMPARISON OF OXIDATION AND REDUCTION METHODS IN THE DETERMINATION OF FORMS OF SULFUR IN COAL," ENVIRONMENTAL GEOLOGY NOTES, NO.66, ILLINOIS STATE GEOLOGY SURVEY, URBANA, ILLINOIS, 1973.

16. MOTT, R. A., WILKINSON, H. C., "DETERMINATION OF SULPHUR IN COAL AND COKE BY THE SHEFFIELD HIGH TEMPERATURE METHOD," STANDARDIZATION OF THE METHODS OF ANALYSIS OF COAL AND COKE, XI, PP. 6-17, 1954

17. POWELL, A. R., "THE FORMS OF SULFUR IN COKE, A PHYSIOCHEMICAL STUDY OF THE SULFUR HELD BY CARBON AT HIGH TEMPERATURES," JOURNAL OF THE AMERICAN CHEMICAL SOCIETY, 45(1), PP. 1-15, 1923. 
$-7 \cdot$

18. RENTON, J. J., BIRD, D. S., "ASSOCIATION OF COAL MACERALS, SULFUR, AND SULFUR SPECIES AND THE IRON DISULPHIDE MINERALS IN THREE COLUMNS OF THE PITTSBURGH COAL," INTERNATIONAL JOURNAL OF COAL GEOLOGY, 17, PP. 21-50, 1991.

19. SECKEL, J. A., "ALTERNATIVE METHOD FOR THE ANALYSIS OF PYRITIC SULFUR IN COAL," PITTSBURGH CONFERENCE ON ANALYTICAL CHEMISTRY AND APPLIED SPECTROSCOPY, PAPER NO. 9, 1977.

20. SELVIG, W. A., FIELDNER, A. C., "SULFUR IN COAL AND COKE: CHECK DETERMINATIONS BY THE ESCHKA, BOMB-WASHING, AND SODIUM PEROXIDE FUSION METHODS," INDUSTRIAL AND ENGINEERING CHEMISTRY, PP. 729-733, 1927.

21. SZINYEI, W. J., ELROD, S. H., "AUTOMATION OF THE ANALYSIS OF SULFUR IN COAL AND COKE," PROCEEDINGS OF THE FIRST INTERNATIONAL COAL TEST CONFERENCE, PP. 27 $31,1989$.

22. YOUNG, R. K., ZAWADZKI, E. A., "THE DETERMINATION OF SULFUR IN COAL-BCR ASHING METHOD," FUEL, 46, PP. 151-152, 1967.

\section{Titrimetric Procedures}

Several researchers have proposed titrimetric alternatives to the turbidimetric determination of sulfate arising from coal and related products $(1-5,7-10,12,13,15)$. Of these, none appear to offer significant advantages over the titrimetric procedures first proposed by Fritz and co-workers in the mid 1950's $(2,3)$. The original methods yield accurate and reproducible results when performed by a skilled analyst. The procedure proposed by Makhija (7) may have some utility if applied to the consecutive determination of several inorganic sulfur species, but is most applicable to waste streams rather than coal itself. Similarly the oxidative titration procedures by Krishna, Pillai, and Tiwari $(6,11,16)$, are more suited to the determination of inorganic sulfur species in streams arising from the processing of coal rather than to the determination of sulfur species in coal itself. Skoog has proposed a titrimetric procedure for the determination of elemental sulfur (14) which could have utility in instances when a coal sample contained abnormally high concentrations of elemental sulfur. 
1. EFFENBERGER, M., "CHELATOMETRIC DETECTION OF SULFATES IN WATER WITH CALCEIN AS AN INDICATOR," COLL. CZECH. CHEM. COMM., 24, P. 682, 1959.

2. FRITZ, J. S., FREELAND, M. Q., "DIRECT TITRIMETRIC DETERMINATION OF SULFATE," ANALYTICAL CHEMISTRY, 26(10), PP. 1593-1595, 1954.

3. FRITZ, J. S., YAMAMURA, S. S., "RAPID MICROTITRATION OF SULFATE," ANALYTICAL CHEMISTRY, 27(9), PP. 1461-1464, 1955.

4. HAARTZ, J. C., ELLER, P. M., HORNUNG, R. W., "CRITICAL PARAMETERS IN THE BARIUM PERCHLORATETTHORIN TITRATION OF SULFATE," ANALYTICAL CHEMISTRY, 51(13), PP. 2293-2295, 1979.

5. HICKS, J. E., FLEENOR, J. E., SMITH, H. R., "THE RAPID DETERMINATION OF SULFUR IN COAL," ANALYTICA CHIMICA ACTA, 68, PP. 480-483, 1974.

6. KRISHNA, P. C. P., INDRASENAN, P., "IODAMINE-T AS AN OXIDIMETRIC TITRANT IN

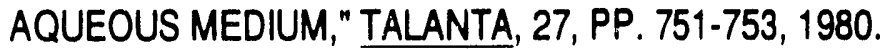

7. MAKHIJA, R., HITCHEN, A., "THE TITRIMETRIC DETERMINATION OF SULPHATE, THIOSULPHATE, AND POLYTHIONATES IN MINING EFFLUENTS, " ANALYTICA CHIMICA ACTA, 105, PP. 375-382, 1979.

8. MARTYNOVA, M. T., NOVITSKII, N. V., "RAPID CONDUCTOMETRIC METHOD FOR DETERMINING TOTAL SULFUR IN COALS," KHIMIIA TVERDOGO TOPLIVA, 4, PP. 136-137, 1968.

9. MELOUN, M., JAVUREK, M., "MULTIPARAMETRIC CURVE FITTING - VI. MRFIT AND MRLET, COMPUTER PROGRAMS FOR ESTIMATION OF THE STABILITY CONSTANT OF THE PREDOMNUNT MPLQ COMPLEX AND THE LIGAND PURITY BY ANALYSIS OF PHOTOMETRIC TITRATION CURVES," TALANTA, 31(12), PP. 1083-1094, 1984.

10. NEAVEL, R., KELLER, J., "ESTIMATION OF SULFUR CONTENT IN COAL FROM TITRATION OF CALORIMETER BOMB WASHINGS," FUEL, 58(6), PP. 402-404, 1979.

11. NOVITSKII, N. V., KHROMYKH, G. I., "A METHOD FOR IAAPID DETERMINATION OF TOTAL SULPHUR IN COALS," TEPLOENERGETIKA, 18(4), PP. 91-92, 1971. 
12. OKHAPKINA, L. L., KUIMOVA, N. N., KAZAKOVA, E. I., TITRIMETRIC DETERMINATION OF TOTAL SULFUR IN COAL," IZV. NAUCH. - ISSLED. INST. NEFTE -UGLEKHIM. SIN. IRKUTSK. UNIV., 11(1), PP. 101-103.

13. PILLAI, C. P. K., INDRASENAN, P., "IODAMINE-T AS AN OXIDIMETRIC TITRANT IN AQUEOUS MEDIUM," SHORT COMMUNICATIONS, 27, PP. 751-753, 1980.

14. SKOOG, D. A., BARTLETT, J. K., "TITRATION OF ELEMENTAL SULFUR WITH SOLUTIONS OF SODIUM CYANIDE," ANALYTICAL CHEMISTRY, 27(3), PP. 369-371, 1955.

15. SZAVA, J., DELY, I., "APPLICATION OF OSCILLOMETRIC TITRATION IN COAL ANALYSIS," FREIBERG FORSCHUNGSH, 405, PP. 81-84, 1967.

16. TIWARI, K. K., VERMA, R. M., "TITRIMETRIC MICRODETERMINATION OF CERTAIN SULPHUR-CONTAINING ORGANIC COMPOUNDS BY OXIDATION WITH ALKALINE POTASSIUM PERMANGANATE," TALANTA, 30(6), PP. 440-442, 1983.

\section{Wet Oxidation}

All papers in this group describe wet digestion procedures to solubilize sulfur in coal as a prelude to its subsequent determination. With one exception, these procedures appear to be more complex and have no advantages over digestion with perchloric acid (discussed in a following section). This exception is the procedure by Finkleman (3) in which pyrite is oxidized with hydrogen peroxide. The rise in $\mathrm{pH}$ during the oxidation provides a rapid, semi-quantitative estimate of the pyrite content of the coal, and quantitative data can be obtained, at the expense of increased time, by determining sulfate in the digestate.

1. ASTHANA, S. S., "DETERMINATION OF TOTAL SULPHUR IN COAL," FUEL, 46(6), PP. 425426, 1967.

2. ASTHANA, S. S., "SIMULTANEOUS DETERMINATION OF TOTAL SULPHUR AND PHOSPHORUS IN COAL," INDIAN JOURNAL OF APPLIED CHEMISTRY, 33(4), PP. 222-224, 1970.

3. FINKELMAN, R., "A RAPID PROCEDURE FOR DETERMINING PYRITIC SULFUR IN COAL," JOURNAL OF COAL QUALITY, 6(2), PP. 50-52, 1987. 
4. MIZOGUCHi, T., ISHI, H., "ANALYTICAL APPLICATIONS OF CONDENSED PHOSPHORIC ACID-IV SULPHUR IN SULPHATE AND SULFIDE ORES," TALANTA, 27, PP. 525-528, 1980.

5. MIZOGUCHI, T., IWAHORI, H., ISHI, H., "ANALYTICAL APPLICATIONS OF CONDENSED PHOSPHORIC ACID-III: DETERMINATION OF SULFUR," TALANTA, 27, PP. 519-524, 1980.

6. PRASAD, N. K., "METHODS, APPARATUS: NEW PRODUCT RESEARCH, PROCESS DEVELOPMENT AND DESIGN," CHEMISTRY AND INDUSTRY, PP. 444-445, 1968.

7. RAWAT, N., "DETERMINATION OF TOTAL SULPHUR IN SOME INDIAN COALS BY OXIDISING ACID MIXTURE OF POTASSIUM PERMANGANATE AND PEROXYMONOPHOSPHORIC ACID," CHEMISTRY AND INDUSTRY, 17, PP. 743-744, 1976.

8. VASSERMAN, L., GORELOV, P., "ACCELERATED DIFFERENTIATED DETERMINATION OF MINERAL FORMS OF SULFUR IN COAL," KOKS I KHIMIYA, 6, PP. 11-14, 1984.

\section{Nitric Acid Extraction}

Organic sulfur is determined in the ASTM procedure by the difference between the value for total sulfur and values for pyritic and sulfatic sulfur. The value obtained for organic sulfur is, thus, subject to the cumulative effect of any errors or uncertainties in the determination of total sulfur, pyritic sulfur, and sulfatic sulfur. Edwards (1) and Shimp (7) have reported that at least some pyrite remains in coal after nitric acid extraction. Given (3) reported that using particle sizes slightly larger or smaller than recommended by ASTM procedures has no significant effect on extraction of pyrite with nitric acid. Riley has proposed determining total sulfur in the residue after the extraction of pyrites as a direct measure of the organic sulfur content of coal (4-6). This procedure may have some applications for use in checking the results of ASTM determinations on unusual coal samples, but it appears to be subject to the same uncertainties as the ASTM procedures and introduces new uncertainties. If the ASTM extractions for sulfatic and pyritic sulfur are efficient and no organic sulfur is removed from the coal during the nitric acid extraction, then the results obtained by difference and by performing a total sulfur analysis on the residue should be identical. However, if some sulfatic or pyritic sulfur remains in the coal, organic sulfur values obtained by difference and by performing a total sulfur analysis on the residue will both be too high. On the other hand, if the nitric acid extraction removes 
some of the organic sulfur from the coal, the ASTM procedure should provide a more accurate value than is obtained by performing a total sulfur determination on the residue. Friedman (2) has reported that in general the values obtained by difference and by performing total sulfur analyses on residues are comparable.

1. EDWARDS, A. H., JONES, J. M., NEWCOMBE, W., "THE EXTRACTION BY NITRIC ACID OF PYRITES FROM VITRAINS AND COAL SAMPLES," FUEL, 43, PP. 55-62, 1964.

2. FRIEDMAN, S., "SULFUR ANALYSES OF COAL - A CRITICAL EVALUATION," PROCEEDINGS: FIRST INTERNATIONAL SYMPOSIUM ON THE BIOLOGICAL PROCESSING OF COAL, (EPRI GS 6970), PP. 1-3-1-14, 1990.

3. GIVEN, P. H., MILLER, R. N., "DETERMINATION OF FORMS OF SULPHUR IN COALS," FUEL, 57(6), PP. 380-381, 1978.

4. RILEY, J. T., RUBA, G. M., LEE, C. C., "DIRECT DETERMINATION OF TOTAL ORGANIC SULFUR IN COAL," AMERICAN CHEMICAL SOCIETY SYMPOSIUM SERIES 429: GEOCHEMISTRY OF SULFUR IN FOSSIL FUELS, W. L. ORR, C. M. WHITE, EDS., ACS, WASHINGTON, D. C., PP. 231-240, 1990.

5. RILEY, J. T., RUBA, G. M., "COMPARISON OF SULPHUR IN HNO 3 -EXTRACTED AND PHYSICALLY CLEANED COALS, " FUEL, 68, PP. 1594-1597, 1989.

6. RILEY, J. T., ZHU, M., COFFEY, D. S., SADLER, S. G., STIDAM, J. M., GRAHAM, H. D., JR., "DISTRIBUTION OF ORGANIC SULFUR IN RAW AND SOLVENT EXTRACTED COALS," AMERICAN CHEMICAL SOCIETY DIVISION OF FUEL CHEMISTRY PREPRINTS, 36(2), PP. 820-829, 1991.

7. SHIMP, N. F., HELFINSTINE, R., KUHN, J., "DETERMINATION OF FORMS OF SULFUR IN COAL," AMERICAN CHEMICAL SOCIETY DIVISION OF FUEL CHEMISTRY PREPRINTS, 20(2), PP. 99-108, 1975.

\section{Perchloric Acid Digestion}

In 1932, G. Fredrick Smith first reported that the total sulfur content of coal could be determined by converting all sulfur in coal to sulfate by digestion in perchloric acid followed by the subsequent determination of the solubilized sulfate (7). Digestion 
with perchloric acid is still the most effective means for dissolving organic matter as a prelude to trace metal determinations, sulfur determinations, or to other determination in which sample dissolution is required. The effectiveness of perchloric acid digestions arises because hot concentrated perchloric acid is an extremely powerful oxidant. However, cold dilute perchloric acid is at best a very weak oxidant, and the oxidative properties of perchloric acid are directly related to its concentration and temperature. Markuszewski (1-3) and McGowan (4-6) have proposed using the selective oxidizing power of perchloric acid to determine the forms of sulfur in a single sample of coal. Basically they first leach coal with perchloric acid at a low temperature to remove sulfatic sulfur, then at a higher temperature to remove pyritic sulfur, and finally at an even higher temperature to remove organic sulfur. This procedure appears very effective, but appears more complex than the ASTM procedures, and special precautions are required during the use of perchloric acid. Despite these limitations, the perchloric acid digestion procedure does appear very useful as an alternative for coals that cannot be analyzed by ASTM procedures, and other work indicates that the method can be extended to differentiate among different forms of organic sulfur in coal (2).

1. MARKUSZEWSKI, R., "NEW APPROACHES TO THE DIRECT MEASUREMENT OF SULFUR FORMS IN COAL," FIFTEENTH ANNUAL EPRI CONFERENCE ON FUEL SCIENCE, JUNE 19$21,1990$.

2. MARKUSZEWSKI, R., ZHOU, X., CHRISWELL, C. D., "IMPROVED DIFFERENTIATION OF SULFUR FORMS BY SELECTIVE DEGRADATION WITH PERCHLORIC ACID MIXTURES," AMERICAN CHEMICAL SOCIETY DIVISION OF FUEL CHEMISTRY PREPRINTS, 37(1), PP. 417-423, 1992.

3. MARKUSZEWSKI, R., ZHOU, X., STRASZHEIM, W. E., "CHARACTERIZATION OF SULFUR FORMS IN COAL BY OXIDATIVE DEGRADATION," PROCESSING AND UTILIZATION OF HIGH SULFUR COALS IV, P. R. DUGAN, D. R. QUIGLEY, Y. A. ATTIA, EDS., ELSEVIER, PP. AMSTERDAM, 43-54, 1991.

4. MCGOWAN, C. W., CATES, K. Q., MARKUSZEWSKI, R., THE CONVERSION OF ORGANIC SULFUR IN COAL TO SULFATE USING PERCHLORIC ACID," AMERICAN CHEMICAL SOCIETY DIVISION OF FUEL CHEMISTRY PREPRINTS, 33(1), PP. 225-231, 1988.

5. MCGOWAN, C. W., MARKUSZEWSKI, R., "FATE OF SULFUR COMPOUNDS IN COAL DURING OXIDATIVE DISSOLUTION IN PERCHLORIC ACID," FUEL PROCESSING TECHNOLOGY, 17, PP. 29-40, 1987. 
6. MCGOWAN, C. W., MARKUSZEWSKI, R., "DIRECT DETERMINATION OF SULPHATE, SULPHIDE, PYRITIC AND ORGANIC SULPHUR IN A SINGLE SAMPLE OF COAL BY SELECTIVE, STEP-WISE OXIDATION WITH PERCHLORIC ACID," FUEL, 67, PP. 1091-1095, 1988.

7. SMITH, G. F., DEEM, A., "DETERMINATION OF SULFUR IN COAL BY PERCHLORIC ACID METHOD," INDUSTRIAL AND ENGINEERING CHEMISTRY: ANALYTICAL EDITION, 4, PP. $227-$ 229, 1932.

\section{Other Methods}

A variety of different chemical treatments have been applied to sulfur groups in coal. The method by Willard (20) for determining sulfate in chromic acid and in chromium plating baths is of interest because this method, which was developed in 1929 , serves as the basis for those still used. Burns (2) has proposed an interesting procedure for the determination of sulfate based upon extraction of the ion pair formed between sulfate and a quaternary ammonium salt into an organic solvent. Ignasiak has proposed a classical wet chemical procedure for determining different organic structures in coal (4). Gadyatskii separated minerals from coal by high temperature extraction using acenaphthalene as the solvent and the determined organic sulfur forms in the residue by chemical procedures (5). Ozdemir extracted coal with isooctane and then determined organosulfur compounds in the extracts by fractionation (14). Several researchers have also studied reactions with methyl lodide $(3,6-10,13,15,18)$. Postowsky demonstrated that thioether groups in coal could be determined based upon their reaction with methyl iodide (15). Kavcic treated coal with acetone followed by methyl iodide to show that sulfur is predominantly in the form of ring structures (10).

1. ATTAR, A, CORCORAN, W. H., "DESULFURIZATION OF ORGANIC SULFUR COMPOUNDS BY SELECTIVE OXIDATION. 1) REGENERABLE AND NONREGENERABLE OXYGEN CARRIERS," INDUSTRIAL CHEMICAL ENGINEERING PRODUCT RESEARCH AND DEVELOPMENT, 17(2), PP. 102-109, 1978.

2. BURNS, D. T., BUSHRA, M., "THE SPECTROPHOTOMETRIC DETERMINATION OF SULPHATE AFTER ITS EXTRACTION WITH METHYLTRICAPRYLAMMONIUM CHLORIDE INTO CYCLOHEXANE," ANALYTICA CHIMICA ACTA, 162, PP. 443-446, 1984. 
3. CASAGRANDE, D. J., SIEFERT, K., "ORIGINS OF SULFUR IN COAL: IMPORTANCE OF THE ESTER SULFATE CONTENT OF PEAT," SCIENCE, 195, PP. 675-676, 1977.

4. IGNASIAK, B. S., FRYER, J. F., JADERNIK, P., "POLYMERIC STRUCTURE OF COAL. 2. STRUCTURE AND THERMOPLASTICITY OF SULPHUR-RICH RASA LIGNITE," FUEL, 57(10), PP. 578-584, 1978.

5. GADYATSKII, V. G., DIDENKO, V. E., PANCHENKO, V. A., GNEZDILOV, O. V., "FEATURES OF THE EVOLUTION OF HYDROGEN SULFIDE IN THE THERMAL DECOMPOSITION OF HARD COALS OF DIFFERENT RANKS," KHIMIYA TVERDOGO TOPLIVA, 14(1), PP. 17- 20, 1980.

6. GUNDERMANN, K. D., FIEDLER, G., KNOPPEL, I., "BEITRAGE ZUR CHEMIE DES DIBENZOTHIOPHENS," ERDOL KOHLE-ERDGAS-PETROCHEMIE BRENNSTOFF-CHEMIE, 29(1), PP. 23-27, 1976.

7. GUNDERMANN, K. D., HOFFMAN, G., SCHENK, N., FIEDLER, G., ZUR BINDUNG DES ORGANISCHEN SCHWEFELS IN STEINKOHLE," JAHRGANG, 25(2), PP. 58-61, 1972.

8. GUSEV, S. I., "PRESENCE OF BISTHIOETHER GROUPS IN KIZELOV BITUMINOUS COALS," ZH. PRIKL. KHIM., (JOURNAL OF APPLIED CHEMISTRY) 17(6), PP. 362-369, 1944.

9. GUSEV, S. I., "QUESTION ON THE PRESENCE OF DIBENZOTHIOPHENE (DIPHENYLENESULFIDE) IN BITUMINOUS COALS," ZH. PRIKL. KHIM., (JOURNAL OF APPLIED CHEMISTRY, 17(3), PP. 178-82, 1944.

10. KAVCIC, R., "THE DETERMINATION OF SULFUR LINKAGE IN THE RASA COAL," BULLETIN SCIENTIFIQUE YOUGOSLAVIE, 2(1), PP. 12-13, 1954.

11. KIZIL'SHTEIN, L. Y., MINAEYA, L. G., "STUDY OF BIOGENIC REDUCTION OF SULFATE IN PEAT IN CONNECTION WITH THE PROBLEM OF THE SULFUR CONTENT OF COAL," KHIMIYA TVERDOGO TOPLIVA, 4, PP. 116-122, 1972.

12. KUSENKO, G., AVGUSHEVICH, J., KULIKOVA, E., "PHASE ANALYSIS OF SULFUR COMPOUNDS IN SOLID ABSORBENTS," KHIMIVA TVERDOGO TOPLIVA, 11 (2), PP. 23-28, 1977. 
13. MARKUSZEWSKI, R., WEI, C. -K, WHEELOCK, T. D., "OXYDESULFURIZATION OF COAL TREATED WITH METHYL IODIDE, IMPLICATIONS FOR REMOVAL OF ORGANIC SULFUR," AMERICAN CHEMICAL SOCIETY DIVISION OF FUEL CHEMISTRY PREPRINTS, 25(2), PP. 187-194, 1980.

14. OZDEMIR, I. H., "QUALITATIVE DETERMINATION OF SULFUR COMPOUNDS IN TURKISH COALS," ISTANBUL TEKNIK UNIVERSITIES BULTENI, 24(1), PP. 28-52, 1971.

15. POSTOWSKY, J. J., HARLAMPOVICH, A. B., "THE PRESENCE OF THIOETHER SULFUR IN ORGANICALLY FIXED SULPHUR OF COALS," FUEL, 15(8), PP. 229-232, 1936.

16. ROLIA, E., BARBEAU, F., "ESTIMATION OF INDIVIDUAL THIO-SALTS AND SULPHATE IN FLOTATION MILL SOLUTIONS," TALANTA, 27, PP. 596-598, 1980.

17. RUBIO, S., GOMEZ-HENS, A., VALCARCEL, M., "FLUOROMETRIC DETERMINATION OF SULPHATE BY TERNARY COMPLEX FORMATION WITH ZIRCONIUM AND BIACETYLMONOXIME NICOTINYLHYDRAZONE," TALANTA, 32(3), PP. 203-206, 1985.

18. SELKER, M. L., KEMP, A. R., "REACTION OF METHYL IODIDE WITH SULFUR COMPOUNDS," INDUSTRIAL AND ENGINEERING CHEMISTRY, 36, PP. 16-28, 1944.

19. STOKES, H., "EXPERIMENTS ON THE ACTION OF VARIOUS SOLUTIONS ON PYRITE AND MARCASITE," ECONOMIC GEOLOGY, 2, PP. 14-23, 1907.

20. WILLARD, H. H., SCHNEIDEWIND, R., "THE DETERMINATION OF SULFATE IN CHROMIC ACID AND IN CHROMIUM PLATING BATHS," TRANSACTIONS OF THE AMERICAN ELECTROCHEMICAL SOCIETY, 56, PP. 333-349, 1929. 
.16

\section{$\underline{X-R A Y ~ P R O C E D U R E S ~}$}

X.RAY Photoelectron Spectroscopy (XPS)/Electron Spectroscopy for Chemical Analysis (ESCA)

XPS or ESCA provides elemental identification and oxidation/functional group information for all elements except hydrogen and helium $(2,9,22)$. It is a surface analysis technique which reaches only the first $3.4 \mathrm{~nm}$ of the sample surface $(12,22)$. The method is based upon ejecting a core electron from a sample with soft, near monochromatic, $x$-rays. The kinetic energy of the ejected electrcns is dotermined, and from this the binding energy of the electron. Because each element has characteristic binding energies, individual elements can be determined. In addition, shifts in binding energies can be used to distinguish among different chemical environments for a given element. XPS is not generally considered as a quantitative technique (7), but reproducibilities as good as $10 \%$ have been attained in some cases (2). Quantitative determinations are hampered by variations in surface topography, crystallinity, and matrix effects. However, relative concentrations of different forms of the same element can be determined with accuracy because the effects are the same for all functional groups. For sulfur, the $2 p$ peaks are examined. The binding energies of organic and pyritic sulfur are both about 163-164 electron volts whereas that of oxidized sulfur species, such as sulfate, are about 168-172 electron volts. Elemental sulfur has a binding energy about 1 electron volt different from that of pyritic sulfur, and the presence of elemental sulfur is theoretically detectable based upon broadening of the pyritic sulfur peak or by using peak deconvolution techniques.

XPS is most useful for determining changes in the forms of sulfur on the surface of coal during treatments. XPS has been used to look at changes in surface concentrations of sulfur during milling and physical cleaning (25). Other studies have involved elucidating the agreement between concentrations of sulfur at the surface obtained by XPS and bulk concentrations obtained by other techniques $(3,4,8,15,21)$. Mixed results on the degree of correlation between surface and bulk concentrations were observed. XPS has also been used to study changes in sulfur form during oxidation $(5,6,8,19,24)$, including chemical oxidation (1). One paper has discussed the use of XPS to semiquantitatively examine pyrite concentration and particle size as a function of particle size (5). Particular attention has been given to identifying different forms of sulfur in coal, including organic sulfur functionalities $(10,13,14,16-18,23)$. Another application of XPS to sulfur in coal is the study of changes in sulfur forms during leaching of coal with hydrochloric and nitric acids (11). 
1. BALTRUS, J. P., DIEHL, J. R., D'ESTE, J. R., LADNER, E. P., "REACTIVITY OF SULFUR ON ALKALI-TREATED COAL SURFACES," PROCEEDINGS OF THE FIFTH ANNUAL INTERNATIONAL PITTSBURGH COAL CONFERENCE, PP. 403-408, SEPTEMBER 12-16, 1988.

2. BORMAN, S. "RECENT DEVELOPMENTS IN XPS," ANALYTICAL CHEMISTRY, 599(6), PP. 461A-462A, 1987.

3. CLARK, D. T., WILSON, R., "ESCA APPLIED TO ASPECTS OF COAL SURFACE CHEMISTRY," FUEL, 62, PP. 1034-1040, 1983.

4. CLARK, D. T., WILSON, R., QUIRKE, J. M. E., "AN EVALUATION OF THE POTENTIAL OF ESCA (ELECTRON SPECTROSCOPY FOR CHEMICAL APPLICATIONS) (AND OTHER SPECTROSCOPIC TECHNIQUES) IN THE SURFACE AND BULK CHARACTERIZATION OF KEROGENS, BROWN COAL AND GILSONITE," CHEMICAL GEOLOGY, 39, PP. 215-239, 1983.

5. CHAN, P. K., FROST, D. C., "AN INVESTIGATION OF THE EFFECT OF PARTICLE SIZE ON OXIDATION OF PYRITES IN COAL," SPIE, 690X-RAYS IN MATERIALS ANALYSIS: NOVEL APPLICATIONS AND RECENT DEVELOPMENTS, PP. 101-106, 1986.

6. FROST, D. C., LEEDER, W. R., TAPPING, R. L, WALLBANK, B., "AN XPS STUDY OF THE OXIDATION OF PYRITE AND PYRITES IN COAL," FUEL, 56(3), PP. 277-280, 1977.

7. FROST, D. C., WALLBAINK, B., LEEDER, W. R., "X-RAY PHOTOELECTRON SPECTROSCOPY OF COAL AND COAL RELATED PROBLEMS," ANALYTICAL METHODS FOR COAL AND COAL PRODUCTS, VOLUME I, C. KARR, JR., ED., ACADEMIC PRESS, NEW YORK, PP. 349-376, 1978.

8. FROST, D. C., LEEDER, W. R., TAPPING, R. L, "X-RAY PHOTOELECTRON SPECTROSCOPIC INVESTIGATION OF COAL," FUEL 53, PP. 206-211, 1974.

9. GRINT, A., PERRY, D. L., THE USE OF XPS AS A PROBE OF THE ELEMENTAL AND FUNCTIONAL GROUP COMPOSITION OF COAL," PROCEEDINGS OF THE 1983 INTERNATIONAL CONFERENCE OF COAL SCIENCE, PITTSBURGH, PENNSYLVANIA, PP. 655-658, AUGUST 15-19, 1983.

10. HIROKAWA, K., DANZAKI, Y., "ANALYTICAL APPLICATION OF XPS FOR SURFACE CHARACTERIZATION OF COAL FLY ASH AND COAL," SURFACE AND INTERFACE ANALYSIS 6(4), PP. 193.195, 1984. 
11. HITTLE, L., SHARKEY, A. G., HOUALLLA, M., HERCULES, D. M., MORSI, B. I.,"DETERMINATION OF SULFUR FORMS ON COAL SURFACES BY ESCA," PROCEEDINGS OF THE EIGHTH ANNUAL INTERNATIONAL PITTSBURGH COAL CONFERENCE, PP. 1181 $1185,1991$.

12. JONES, R. B., MCCOURT, C. B., SWIFT, P., "XPS STUDIES OF NITROGEN AND SULPHUR IN COAL," PROCEEDINGS OF THE 1981 INTERNATIONAL CONFERENCE ON COAL SCIENCE, VERLAG GLUCKAUF GMBH, ESSEN, GERMANY, PP. 657-662, 1981.

13. KELEMEN, S. R, GEORGE, G. N., GORBATY, M. L., "DIRECT DETERMINATION AND QUANTIFICATION OF ORGANIC SULFUR FORMS BY X-RAY PHOTOELECTRON SPECTROSCOPY (XPS) AND SULFUR K-EDGE ABSORPTION SPECTROSCOPY," FUEL PROCESSING TECHNOLOGY, 24, PP. 425-429, 1990.

14. KELEMEN, S. R., GEORGE, G. N., GORBATY, M. L., "DIRECT DETERMINATION AND QUANTIFICATION OF SULFUR FORMS IN HEAWY PETROLEUM AND COALS: 1 . THEX-RAY PHOTOELECTRON SPECTROSCOPY (XPS) APPROACH," FUEL, (69), PP. 939-944, 1990.

15. KELEMEN, S. R., FREUND, H., "APPLICATION OF X-RAY PHOTOELECTRON SPECTROSCOPY TO COAL OXIDATION KINETICS," AMERICAN CHEMICAL SOCIETY DIVISION OF FUEL CHEMISTRY PREPRINTS, 33(4), PP. 706-722, 1988.

16. KELEMEN, S. R., GEORGE, G. N., GORBATY, M. L., "DIRECT DETERMINATION AND QUANTIFICATION OF SULFUR FORMS BY X-RAY PHOTOELECTRON SPECTROSCOPY (XPS) AND SULFUR K-EDGE ABSORPTION SPECTROSCOPY," SECOND INTERNATIONAL SYMPOSIUM ON COAL SCIENCE, ROLDUC, NETHERLANDS, MAY 21-25, 1989.

17. KELEMEN, S. R., GEORGE, G. N., GORBATY, M. L., "DIRECT DETERMINATION AND QUANTIFICATION OF SULFUR FORMS IN HEAWY PETROLEUM AND COALS: PARTI. THE XRAY PHOTOELECTRON SPECTROSCOPY (XPS) APPROACH," AMERICAN CHEMICAL SOCIETY DIVISION OF FUEL CHEMISTRY PREPRINTS, 34(3), PP. 729-737, 1989.

18. KELEMEN, S. R., GORBATY, M. L., GEORGE, G. N., KWIATEK, P. J., "SURFACE COMPOSITION OF IRON AND INORGANIC SULFUR FORMS IN ARGONNE PREMIUM COALS BY X-RAY PHOTOELECTRON SPECTROSCOPY," ENERGY AND FUELS, 5, PP. 720-723, 1991. 
19. LAI, R. W., DIEHL, J. R., HAMMACK, R. W., KHAN, S. U. M., "COMPARATIVE STUDY OF THE SURFACE PROPERTIES AND THE REACTIVITY OF COAL PYRITE AND MINERAL PYRITE," SME ANNUAL MEETING, PREPRINT NUMBER 89-6, SOCIETY OF MINERAL ENGINEERS, LITTLETON, COLORADO, 1989.

20. MCINTYRE, N. S., MARTIN, R. R., CHAUVIN, W. J., WINDER, C. G., BROWN, J. R., MACPHEE, J. A., "STUDIES OF ELEMENTAL DISTRIBUTIONS WITHIN DISCRETE COAL MACERALS: USE OF SECONDARY ION MASS SPECTROMETRY AND X-RAY PHOTOELECTRON SPECTROSCOPY, ${ }^{\circ}$ FUEL, 64, PP. 1705-1712, 1985.

21. PERRY, D. L., GRINT, A., "APPLICATION OF XPS TO COAL CHARACTERIZATION," FUEL, 62, PP. 1024-1033, 1983.

22. PERRY, D. L., GRINT, A., "FUNCTIONAL GROUP ANALYSIS OF COAL AND COAL PRODUCTS BY X-RAY PHOTOELECTRON SPECTROSCOPY," AMERICAN CHEMICAL SOCIETY DIVISION OF FUEL CHEMISTRY PREPRINTS, 31(1), PP. 107-115, 1986.

23. SCHULTZ, H. D., PROCTOR, W. G., "APPLICATION OF ELECTRON EMISSION SPECTROSCOPY TO CHARACTERIZE SULFUR BONDS IN COAL," APPLIED SPECTROSCOPY, 27(5), PP. 347-351, 1973.

24. WEITZSACKER, C. J., SCHMIDT, J. J., GARDELLA, J. A., JR., "AGING STUDIES OF BITUMINOUS COAL BY ESCA AND FTIR," AMERICAN CHEMICAL SOCIETY DIVISION OF FUEL CHEMISTRY PREPRINTS, 35(2), PP. 344-351, 1990.

25. WEITZSACKER, C. J., SCHMIDT, J. J., GARDELLA, J. A., JR., "ESCA AND FTIR STUDIES OF BITUMINOUS COAL," AMERICAN CHEMICAL SOCIETY DIVISION OF FUEL CHEMISTRY PREPRINTS, 34(2), PP. 545-550, 1989.

\section{Electron Mlaroprobe, SEM-EDX and Automated Image Analysis Techniques}

Sulfur form analyes by these techniques is primarily by analysis of the $S K_{A} x$-ray emission. There have been different approaches taken with regard to instrumentation, detectors and sample geometry.

Much of the initial work was performed using electron beam microprobes with wavelength-dispersive $x$-ray spectrometers $(1,4,7,17,18,30,35)$. This instrumentation 
was designed for quantitative $x$-ray analysis of metallurgical and geological samples with a view to beam stability and optimized count rates. These systems worked fairly well on coal samples and much valuable information was obtained. Harris and co-workers (7) showed the consistent differences in sulfur content between macerals (exinite>vitrinite>inertinite as a rule). Harris, Raymond and Gooley developed a reasonably fast protocol and a petroleum coke standard for sulfur (6). Their later work (17) involved analyzing 15 grains of vitrinite alone for a very fast measure of sulfur content.

With the advent of energy-dispersive $x$-ray analyzers and quantitative analysis software for those analyzers, it became possible to extend sulfur analysis to scanning electron microscopes (SEMs) $(2,3,5,15,20,21,22)$, and transmission and scanning transmission electron microscopes (TEMs and STEMs)(9-11,31-34). Energy-dispersive analyzers were needed since they afford a much higher count rate for the same beam current, and these latter microscopes operate at orders of magnitude less current than do microprobes.

Straszheim and co-workers were among the first to demonstrate this technique on an SEM. Their work involved estimating the variation in sulfur content among particles and within particles. The technique was also applied to samples of chemically and biologically processed coals. In some cases, a decrease in organic sulfur content was observed. In a number of cases, however, no statistically significant change in sulfur content was observed even though ASTM sulfur forms analyses (applied out of context because ASTM procedures have not been tested for such samples) did indicate a change. Maijgren et al. have also applied the technique to chemically processed coals (14). Kaegi (13) used essentially the same technique to study organic sulfur and chlorine in Illinois basin coals.

Wert and co-workers produced many notable papers dealing with the analysis of organic sulfur using a TEM. Sample preparation is more difficult for a TEM because the sample must be thin in order to allow a large fraction of the electrons to pass through the sample. However, use of thin samples does lead to an increase in spatial resolution. Wert and co-workers used the increased resolution to advantage in studying the sulfur gradient near pyrite inclusions. They found little or no 
$-21-$

evidence of a sulfur gradient in raw coals. However, they did document the incorporation o! sulfur from pyrite as organic sulfur upon heating samples above the pyrite decomposition temperature $\left(450^{\circ} \mathrm{C}\right)$.

The above techniques focused on the direct analysis of organic sulfur. There have veen some efforts directed towards analysis of all relevant sulfur forms. Straszheim and co-workers (23-29) have used image analysis to determine the sulfatic and pyritic sulfur contents from the area of pyrite and sulfate minerals in a polished section of coal in an embedding media. Solomon et al. (19) at Advanced Fuel Research have employed a novel approach to the simultaneous rapid analysis on all sulfur forms. They used a pellet formed from ground coal alone, i.e., no binder. They scanned areas of a size that would contain varying amounts of pyritic sulfur. Plots of sulfur vs. iron concentrations for all regions analyzed provided a measure of iron-sulfur stoichiometry from the slope of the fitted line, and the intercept at $0 \%$ iron indicated the organic sulfur content.

Moza et al. developed a technique which located particles and collected $x$-ray data for representative areas covering the entire particle (16). Thus, an overall chemical analysis was obtained. However, the subject of these investigations was ash chemistry, not sulfur analysis. Hurley and White (12) used x-ray fluorescence to determine the forms of sulfur in coal. They used the shape of the $S K_{B}$ line to determine total sulfur content and to assign sulfur to pyritic and organic forms. This method was reasonably fast, but of course did not permit any spatial resolution of sulfur because it used an incident $x$-ray beam rather than a finely focused electron beam.

1. BOATENG, D., PHILLIPS, C., "EXAMINATION OF COAL SURFACES BY MICROSCOPY AND THE ELECTRON MICROPROBE," FUEL, 55(4), PP. 318-322, 1976.

2. CLARK, C. P., FREEMAN, G. B., HOWER, J. C., "NON-MATRIX CORRECTED ORGANIC SULFUR DETERMINATION BY ENERGY DISPERSIVE X-RAY SPECTROSCOPY FOR WESTERN KENTUCKY COALS AND RESIDUES," SCANNING ELECTRON MICROSCOPY, II, PP. 537-545, 1984. 
3. DUNSTAN, B. T., "ORGANIC SULPHUR IN COAL AND COKE BY SCANNING ELECTRON MICROSCOPY-ENERGY DISPERSIVE X-RAY ANALYSIS," AUSTRALIAN COAL SCIENCE CONFERENCE, PP. A2/7.1-A2/7.8, 1988.

4. FRIEL, J., MITCHELL, G., "ORGANIC OXYGEN AND SULFUR ANALYSIS OF VARIOUS COAL MACERALS," MICROBEAM ANALYSIS, 16, PP. 148-150, 1981.

5. GREER, R. T., "ORGANIC AND INORGANIC SULFUR IN COAL," SCANNING ELECTRON MICROSCOPY, 1, SEM INC., AMF O'HARE, ILLINOIS, 1979.

6. HARRIS, L. A., RAYMOND, R., JR., GOOLEY, R., "A NEW IMPROVED STANDARD FOR ELECTRON PROBE DETERMINATION OF ORGANIC SULFUR IN FOSSIL FUELS," MICROBEAM ANALYSIS, PP. 147-148, 1980.

7. HARRIS, L. A., YUST, C. S., CROUSE, R. S., "DIRECT DETERMINATION OF PYRITIC AND ORGANIC SULPHUR BY COMBINED COAL PETROGRAPHY AND MICROPROBE ANALYSIS (CPMA): A FEASIBILITY STUDY," FUEL, 56, PP. 456-457, 1977.

8. HEMENS, C. M., HAYTHORNTHWAITE, R. F., NANDI, B. N., "ENERGY DISPERSIVE X-RAY MICROPROBE ANALYSIS OF MATERIALS CONTAINING LIGHT ELEMENTS USING PEAK RATIOS," SCANNING, 12(5), PP. 253-256, 1990.

9. HSIEH, K. C., WERT, C. A., "DIRECT MEASUREMENT OF ORGANIC SULFUR IN COAL," FUEL, 64, PP. 255-262, 1985.

10. HSIEH, K., TSENG, B., BUCKENTIN, M.; WERT, C., DYRKACZ, G., "MEASUREMENT OF ORGANIC SULFUR IN FOSSIL FUELS," AMERICAN CHEMICAL SOCIETY DIVISION OF FUEL CHEMISTRY PREPRINTS, 30 (1), PP. 37-46, 1985.

11. HSIEH, K., WERT, C., "MEASUREMENT OF ORGANIC SULFUR IN COAL," PROCEEDINGS OF THE INTERNATIONAL CONFERENCE ON COAL SCIENCE, SYDNEY, AUSTRALIA, PP. 826829, OCT. 1985.

12. HURLEY, R. G., WHITE, E. W., "NEW SOFT X-RAY METHOD FOR DETERMINING THE CHEMICAL FORMS OF SULFUR IN COAL," ANALYTICAL CHEMISTRY, 46(14), PP. 2234-2237, 1974. 
13. KAEGI, D. D., HAMLING, J. W., "ELECTRON MICROPROBE CHARACTERIZATION OF CHLORINE AND SULFUR IN ILLINOIS BASIN COALS, "PROCEEDINGS OF THE SECOND ANNUAL PITTSBURGH COAL CONFERENCE, PITTSBURGH, PENNSYLVANIA, PP. 273-285, SEPT. 16-20, 1985.

14. MAIJGREN, B., HUBNER, W., NORREGARD, K., SUNDVALL, S. -B, "DETERMINATION OF ORGANIC SULFUR IN CHEMICALLY CLEANED COALS BY SCANNING ELECTRON MICROSCOPY AND ENERGY DISPERSIVE X-RAY SPECTROMETRY," FUEL, 1983.

15. MARKUSZEWSKI, R., MILLER, L. J., STRASZHEIM, W. E., FAN, C. W., WHEELOCK, T. D., GREER, R. T., "EVALUATION OF THE REMOVAL OF ORGANIC SULFUR FROM COAL," NEW APPROACHES IN COAL CHEMISTRY, ACS SYMPOSIUM SERIES NO. 169, B. D. BLAUSTEIN, B. C. BOCKRATH, S. FRIEDMAN, EDS., PP. 401-414, AMERICAN CHEMICAL SOCIETY, WASHINGTON, D. C., 1981.

16. MOZA, A., AUSTIN, L., "ANALYSIS OF PULVERIZED COAL PARTICLES (10-100 um) FOR IRON, SULFUR, CALCIUM, SILICON, AND ALUMINUM ON A PARTICLE-BY-PARTICLE BASIS," FUEL, 62(12), PP. 1468-1473, 1983.

17. RAYMOND, R., DAVIES, T., HAGAN, R., "STATISTICAL VALIDITY FOR ELECTRON PROBE. MICROANALYSIS OF ORGANIC SULFUR IN COAL," PROCEEDINGS OF THE 15TH ANNUAL CONFERENCE OF THE MICROBEAM ANALYSIS SOCIETY, PP. 149-150, 1980.

18. RAYMOND, R., JR., GREGORY, T. G., GODEY, R., "ELECTRON MICROANALYSIS OF ORGANIC SULFUR IN COAL," PROCEEDINGS OF THE 12TH ANNUAL CONFERENCE OF THE MICROBEAM ANALYSIS SOCIETY, PP. 177A-177D, 1977.

19. SOLOMON, P. R., MANZIONE, A. V., "NEW METHOD FOR SULFUR CONCENTRATION MEASUREMENTS IN COAL AND CHAR," FUEL, 56, PP. 393-396, 1977.

20. STRASZHEIM, W. E., GEER, G. T., "DIRECT DETERMINATION OF ORGANIC SULFUR IN COAL WITH ESTIMATES OF INTRA- AND INTER-PARTICLE VARIATION," SCANNING ELECTRON MICROSCOPY/1982/III, SEM INC., AMF O'HARE, ILLINOIS, PP. 1013-1024, 1983.

21. STRASZHEIM, W. E., THE DIRECT DETERMINATION OF ORGANIC SULFUR IN COAL BY ELECTRON BEAM MICROANALYSIS, MASTER'S THESIS, DEPARTMENT OF ENGINEERING SCIENCE AND MECHANICS, IOWA STATE UNIVERSITY, AMES, IOWA, 1981. 
22. STRASZHIEM, W. E., GEER, R. T., MARKUSZEWSKI, R., "DIRECT DETERMINATION OF ORGANIC SULFUR IN RAW AND CHEMICALLY DESULFURIZED COALS," FUEL, 62(9), PP. 1070-1075, 1983.

23. STRASZHEIM, W. E., APPLICATION OF AUTOMATED IMAGE ANALYSIS TO THE STUDY OF MINERAL MATTER IN RAW AND PROCESSED COALS, DOCTORAL DISSERTATION, DEPARTMENT OF ENGINEERING SCIENCE AND MECHANICS, IOWA STATE UNIVERSITY, AMES, IOWA, 1986.

24. STRASZHEIM, W. E., MARKUSZEWSKI, R., "APPLICATION OF SCANNING ELECTRON MICROSCOPY AND AUTOMATED IMAGE ANALYSIS FOR CHARACTERIZATION OF MINERAL MATTER IN COAL," AMERICAN CHEMICAL SOCIETY DIVISION OF FUEL CHEMISTRY PREPRINTS, 30(1), PP. 47-55, 1985.

25. STRASZHEIM, W. E., MARKUSZEWSKI, R., "AUTOMATED IMAGE ANALYSIS OF MINERALS AND THEIR ASSOCIATION WITH ORGANIC COMPONENTS IN BITUMINOUS COALS FROM THE ARGONNE PREMIUM COAL SAMPLE PROGRAM," ENERGY AND FUELS, 4(6), PP. 748$754,1990$.

26. STRASZHEIM, W. E., MARKUSZEWSKI, R., POLLARD, J. L., NORTON, G. A., "CHARACTERIZATION OF THE CLEANABILTTY OF HIGHER-SULFUR NORTH DAKOTA LIGNITES," PROCESSING AND UTILIZATION OF HIGH SULFUR COALS IV, P. R. DUGAN, D. R. QUIGLEY, AND Y. A. ATTIA , EDS., ELSEVIER, AMSTERDAM, PP. 55-70, 1991.

27. STRASZHEIM, W. E., MARKUSZEWSKI, R., "ADVANCES IN THE QUANTITATIVE ASSESSMENT OF THE ASSOCIATION OF MINERAL MATTER WITH COAL," ADVANCES IN COAL SCIENCE, (ACS SYMPOSIUM SERIES NO. 461), H. H. SCHOBERT, K. D. BARTLE, AND L. J. LYNCH, EDS., AMERICAN CHEMICAL SOCIETY, WASHINGTON, D.C., PP. 31-43, 1991.

28. STRASZHEIM, W. E., YOUSLING, J. G., MARKUSZEWSKI, R., "AUTOMATED IMAGE ANALYSIS OF MINERAL MATTER IN RAW AND SUPERCLEANED COALS," MINERAL MATTER AND ASH IN COAL, ACS SYMPOSIUM SERIES NO. 301, K. S. VORRES, ED., AMERICAN CHEMICAL SOCIETY, WASHINGTON, D. C., PP. 449-461, 1986.

29. STRASZHEIM, W. E., YOUSLING, J. G., YOUNKIN, K. A., "MINERALOGICAL CHARACTERIZATION OF LOWER RANK COALS BY SEM-BAGED AUTOMATED IMAGE ANALYSIS AND ENERGY-DISPERSIVE X-RAY SPECTROMETRY," FUEL, 67(8), PP. 1042 1047, 1988. 
30. SUTHERLAND, J. K., "DETERMINATION OF ORGANIC SULFUR IN COAL BY MICROPROBE," FUEL, 54, P. 132, 1975.

31. TSENG, B. H., BUCKENTIN, M., HSIEH, K. C., WERT, C. A., DYRKACZ, G. R., "ORGANIC SULPHUR IN COAL MACERALS," FUEL, 65, , PP. 385-389, 1986.

32. TSENG, B. H., GE, Y. P., HSIEH, K. C., WERT, C. A., "LOSS OF ORGANIC SULPHUR FROM COAL DURING HEATING," PROCESSING AND UTILIZATION OF HIGH SULFUR COALS $\|, Y$. P. CHUGH AND R. D. CAUDLE, EDS., ELSEVIER, PP. 33-40, 1987.

33. WERT, C. A., GE, Y. P., TSENG, B. H., HSIEH, K. C., "ANALYSIS OF ORGANIC SULFUR IN COAL BY USE OF TRANSMISSION ELECTRON MICROSCOPY," JOURNAL OF COAL QUALITY, 7(4), PP. 118-121, 1988.

34. WERT, C., HSIEH, K. C., TSENG, B. H., GE, Y. P., "APPLICATIONS OF TRANSMISSION ELECTRON MICROSCOPY TO COAL CHEMISTRY," FUEL, 66 (7), PP. 914-920, 1987.

35. YU, J., "DETERMINATION OF ORGANIC SULFUR IN COAL WITH ELECTRON MICROPROBE ANALYSIS AIDED BY VITRINITE REFLECTANCE, " YANUANG CESHI, 8(3), PP. 233-235, 1989.

\section{X-Ray Diftraction}

$X$-ray diffraction (XRD) provides a means for identifying and in some cases quantifying crystalline materials such as pyrite in coal. Pollack (3) demonstrated the feasibility of determining pyrite in coal by analyzing mixtures of pyrite and activated carbon. Paris (2) determined total sulfur in coal by XRF and pyrite by XRD. As early as 1973, Schehl (4) computerized an XRD system for determining pyrite in coal. Other workers $(1,5-7)$ have explored the effects of experimental variables on XRD determinations.

1. JAMES, R. G., SEVERN, M. I., "THE EFFECT OF PARTICLE SIZE ON THE DETERMINATION OF PYRITIC SULPHUR," FUEL, 46(6), PP. 476-478, 1967.

2. PARIS, B., SCHUMACHER, P., "SULFUR DISTRIBUTION STUDIES OF COALS AND AIR SAMPLES USING COMMERCIALLY AVAILABLE XRF AND XRD INSTRUMENTS," ELECTRON MICROSCOPY AND X-RAY ANALYSIS APPLIED TO ENVIRONMENTAL OCCUPATIONAL HEALTH ANALYSIS, PP. 93-105, 1977. 
3. POLLACK, S. S., "QUANTITATIVE ANALYSIS OF PYRITE IN COAL," FUEL, 50(4), PP. 453-454, 1971.

4. SCHEHL, R. R., FRIEDEL, R. A., "COMPUTERIZED SYSTEM FOR QUANTITATIVE X-RAY DIFFRACTION ANALYSIS OF PYRITE IN COAL," NTIS NO. 221867/5, 1973.

5. WERTZ, D. L., "MASS ABSORPTION CORRECTED X-RAY DIFFRACTOGRAMS, PART I. MEASURING PYRITE IN POWDERED COALS," POWDER DIFFRACTION, 5(1), PP. 44-47, 1990.

6. WERTZ, D. L., "X-RAY ANALYSIS OF THE ARGONNE PREMIUM COALS. 1. USE OF ABSORPTIONDIFFRACTION METHODS," ENERGY AND FUELS, 4, PP. 442-447, 1990.

7. YASUDA, S., KAKIYAMA, H., "CHEMICAL STATE ANALYSIS OF SULFUR IN COALS AND PETROLEUM PITCHES BY X-RAY EMISSION SPECTROSCOPY," KYUSHU KOGYO GIUUTSU SHIKENSHO MOKOKU, 25, PP. 1553-1560, 1980.

\section{$\underline{X-R a y ~ F l u o r e s c e n c e ~}$}

$X$-ray fluorescence (XRF) methods for the determination of sulfur in coal are based upon the irradiation of samples with high-intensity $x$-rays to cause the fluorescence of $x$-ray photons characteristic of elements. The intensity of the line at 5.373 Angstroms is a measure of the total sulfur content of a sample. A variation of XRF is proton-induced $x$-ray emission (PIXIE), in which the coal sample is bombarded with protons to produce the characteristic $x$-rays.

XRF is a rapid, relatively inexpensive, technique applicable to sulfur concentrations ranging from part per million to percent concentrations. Several investigators have reported on its applicability to coal and coal-related materials $(1,2,5,6,12,13,16$ 20,22). XRF methods are subject to matrix effects which must be compensated for in order to obtain reliable data. Much of the work reported in the literature discusses ways to overcome those effects. Weber (21) oxidized and fused coal into a borax bead containing lead oxide which was used as an internal standard. Page (14) attempted to determine pyrite based on an XRF determination of iron. Paris (15) determined total sulfur by XRF and pyritic sulfur by XRD. Kimura (10-11) corrected results based on the concentration of other elements. Bhan (3) supplemented PIXIE results with those obtained by Mossbauer. Frigge (7) reported improved results after 
grinding coal to a very fine particle size. Botto (4) dissolved coal completely and determined sulfur by XRF in the resulting solution. Furuya (8) employed a double crystal, high resolution XRF technique to distinguish among different oxidation states of sulfur in finely ground coal. Hurley (9) used soft $x$-rays and made measurements of the background, the top of the peak, and the sides of the peak to determine the total sulfur content of coal and obtain estimates of the concentration of forms of sulfur.

1. AUERMANN, R., RUSS, J. C., SHEN, R. B., "ROUTINE ENERGY DISPERSIVE ANALYSIS OF SULFUR IN COAL," ADVANCES IN X-RAY ANALYSIS, 23, PP. 65-69, 1980.

2. BERMAN, M., ERGUN, S., "ANALYSIS OF SULPHUR IN COALS BY X-RAY FLUORESCENCE," FUEL, 47, PP. 285-301, 1968.

3. BHAN, C., CHATURVEDI, S., RAJ, D., NATH, N., "ENERGY DISPERSIVE X-RAY FLUORESCENCE AND MOSSBAUER SPECTROSCOPIC CHARACTERIZATION OF COAL," NUCLEAR GEOPHYSICS, 1(4), PP. 353-356, 1987.

4. BOTTO, R., WHITE, B., KARCHMER, J., HERSCHEL, J., "ANALYSIS FOR SULFUR IN COAL ASH," FUEL, 59, PP. 157-160, 1980.

5. CECHAK, T., HALLY, J., SIMON, L., "PROCESS FOR THE DETERMINATION OF TOTAL SULFUR IN COAL," CZECH. CS 262,318 (CI.GOIN33/22), (PATENT DOCUMENT), JULY, 14, 1989.

6. DEKALB, E., FASSEL, V., "ENERGY DISPERSIVE X-RAY FLUORESCENCE ANALYSIS OF COAL," PROCEEDINGS OF THE ERDA SYMPOSIUM ONX-GAMMA-RAYS, PP. 209-210, 1976.

7. FRIGGE, V. J., "X-RAY FLUORESCENCE ANALYSIS OF SULFUR IN COAL," ERDOL UND KOHLE, 18, PP. 447-451, 1972.

8. FURUYA, K., KATO, Y., KIKUCHI, T., GOHSHI, Y., "STATE ANALYSIS OF SULFUR IN COAL AND COAL FLY ASH BY DOUBLE-CRYSTAL X-RAY FLUORESCENCE SPECTROMETRY," MIKROCHIMIC ACTA, II, PP. 263-270, 1983.

9. HURLEY, R. G., WHITE, E. W., "NEW SOFT X-RAY METHOD FOR DETERMINING THE CHEMICAL FORMS OF SULFUR IN COAL," ANALYTICAL CHEMISTRY, 46(14), PP. 2234-2237, 1974. 
10. KIMURA, T., "DETERMINATION OF SULFUR IN COALS BY X-RAY FLUORESCENCE," JOURNAL OF THE FUEL SOCIETY, 66(1), 34-36, 1987.

11. KIMURA, T., "DETERMINATION OF SULFUR IN COALS BY X-RAY FLUORESCENCE METHOD (II)," JOURNAL OF THE FUEL SOCIETY, 66(2), PP. 107-113, 1987.

12. KOCMAN, $V$., "X-RAY FLUORESCENCE ANALYSIS OF SULPHUR AND TRACE ELEMENTS IN COAL, OIL TAR PITCHES, ASPHALTS AND OTHER BITUMINOUS COMPOUNDS," ADVANCES INX.RAY ANALYSIS, 30, PP. 243-249, 1987, (PROCEEDINGS OF THE 35TH ANNUAL CONFERENCE ON APPLICATIONS OF X-RAY ANALYSIS, HELD AUG. 4-8,1986 IN DENVER, COLORADO), C. S. BARRETT, J. V. GILFRICH, R.JENKINS, D. E. LEYDEN, J. C. RUSS, AND P. K. PREDECKI, EDS., PLENUM PRESS, NEW YORK, 1987.

13. OHORA, M., "RECENT TECHNICAL SUBJECTS ON OIL SHALE PROJECT DEVELOPMENT," JOURNAL OF THE FUEL SOCIETY, 66(1), 28-34, 1987.

14. PAGE, D., PIGGINS, T., "DEVELOPMENT OF AN X-RAY FLUORESCENCE METHOD FOR ONLINE DETERMINATION OF SULFUR IN COAL," INTERNATIONAL JOURNAL OF APPLIED RADIOACTIVE ISOTOPES, 36(1), PP. 1.5, 1985.

15. PARIS, B., SCHUMACHER, P., "SULFUR DISTRIBUTION STUDIES OF COALS AND AIR SAMPLES USING COMMERCIALLY AVAILABLE XRF AND XRD INSTRUMENTS," ELECTRON MICROSCOPY AND X-RAY ANALYYSIS APPLIED TO ENVIRONMENTAL OCCUPATIONAL HEALTH ANALYSIS, PP. 93-105, 1977.

16. RAO, N., RAGHAVAIAH, C., SATYANARANA, G., SASTRY, D., "ELEMENTAL ANALYSIS OF COAL ASH USING ENERGY-DISPERSIVE X-RAY FLUORESCENCE," $\underline{X-R A Y}$ SPECTROMETRY, 16(3), PP. 147-148, 1987.

17. SPACEK, F., "APPLICATION OF X-RAY SPECTRAL ANALYSIS TO THE SIZE MEASUREMENT AND EVALUATION OF MICROCONCRETIONS IN COAL," FREIBERG. FORSCHUNGSH, A553, PP. 259-268, 1976.

18. SWIERCZEK, R., "DETERMINATION OF TOTAL SULFUR IN SOME COAL TAR PRODUCTS BY $X$-RAY ABSORPTION," ZESZYTY NAUKOWE POLITECHYNIKI SLASKIEJ, CHEMIII, 50, PP. 311. $313,1970$. 
19. TAKEMAE, M., ESAKS, S., "STUDIES ON THE METHOD FOR DETERMINATION OF ACID POLLUTANTS. DETERMINATION OF SULFUR IN SOLID FUELS BY FLUORESCENCE X.RAY ANALYZER," KYOTO-FU EISEI KOGAI KENKYUSHO NENPO, 36, PP. 79-85, 1989.

20. WALDO, G. S., MULLINS, O. C., PENNER-HAHN, J. E., CRAMER, S. P., "DETERMINATION OF THE CHEMICAL ENVIRONMENT OF SULPHUR IN PETROLEUM ASPHALTENES BY $X$-RAY ABSORPTION SPECTIOSCOPY," FUEL, 61, PP. 53-57, 1982.

21. WEBER, H., VAN WILLIGEN, J., VAN DER LINDEN, W., "DETERMINATION OF TOTAL SULPHUR IN COAL BY X-RAY FLUORESCENCE SPECTROMETRY," ANALYTICA CHIMICA ACTA, 160, PP. 271-275, 1984.

22. WIDAWSKA-KUSMIERSKA, SIESS, K., "DETERMINATION OF TOTAL SULFUR IN COAL BY AN $X$-RAY FLUORESCENCE TECHNIQUE," ZESZTY NAUKOWE POLITECHNIKI SLASKIEJ, GORNICTWO, 102, PP. 33-45, 1979.

\section{Gamma Ray Spectroscopy}

A technique analogous to XRF uses a radioactive sources such as ${ }^{238} \mathrm{Pu},{ }^{252} \mathrm{Cf}$, $241 \mathrm{Am}$, rather than $\mathrm{x}$-ray tubes. Neutrons or prompt gamma rays emitted from the source cause elements in samples to emit gamma rays having characteristic wavelengths. Most of the work in this area involves the development of instrumentation and procedures suitable for on-line sulfur determinations (1,3-6$8,16,18)$ or demonstrations of the capabilities of such instruments $(2,9-15,17,19)$.

1. CZERW, B., SIKORA, T., GOLEBIOWSKI, W., "MEASUREMENT OF TOTAL SULFUR IN COAL WITH RADIOMETRIC SULFUR METER TYPE MSC," ZESZYTY NAUKOWE AKADEMII GORNICZO HUTNICZEJ, 87, PP. 111.124, 1976.

2. FAY, D. A., PAZIRANDEH, A., STRUSS, R. G., WECHTER, M. A., VOIGT, A. F., "DETERMINATION OF SULFUR AND MOISTURE IN COAL USING CAPTURE GAMMA-PAYS," JOURNAL OF RADIOANALYTICAL CHEMISTRY, 43, PP. ?63-374, 1978.

3. GRABOV, P., MIKHAILOV, G., POTAPOV, A., STARCHIK, L., IVASHCHENKO, G., "BRA-9 DEVICE FOR DETERMINING SULFUR AND ASH CONTENT IN COALS," KOKS I KHIMIYA, 8 , PP. 39-40, 1981. 
4. HALLEY, J., SIMON, L., CECHAK, T., KOC, L., "DETECTOR FOR RADIONUCLIDE SPECTROMETRIC X.RAY FLUORESCENCE ANALYZER FOR DETERMINATION OF TOTAL SULFUR," CZEC. CS 262,733 (CI.GOIN23/223), JANUARY 2, 1990.

5. KOC, L., HALLY, J., CECKAK, T., SIMON, L., "RADIONUCLIDE ANALYZER FOR TOTAL SULFUR CONTENT IN COAL," CZEC. CS 262,474 (CI.GOIN23/02), 5 P., MAY 13, 1987.

6. LANDSBERGER, S., GIOVAGNOLI, A., DEBRUN, J., ALBERT, P., "SULFUR DETERMINATION IN COAL BY PROTON ACTIVATION ANALYSIS," INTERNATIONAL JOURNAL OF ENVIRONMENTAL ANALYTICAL CHEMISTRY, 16(4), PP. 295-303, 1984.

7. OLIVIER, C., PEISACH, M., MORLAND, H., DE WET, B., "SULFUR DETERMINATION BY PROTON-INDUCED PROMPT GAMMA EMISSION: THE EFFECT OF THE MATRIX AND ITS IMPORTANCE IN COAL ANALYSIS," JOURNAL OF RADIOANALYTICAL AND NUCLEAR CHEMISTRY, LETTERS, 106/2/107.122, 1986.

8. ONISHCHENKO, A., BELONOZHKO, V., "ANALYZER FOR THE QUALITY CONTROL ON THE CONVEYOR," ZAVODSKAYA LABORATORIYA, 51 (8), PP. 50.54, 1985.

9. ONISHCHENKO, A., GRABOV, P., POTAPOV, A., "OPTIMIZING INSTRUMENTAL MONITORING OF SULPHUR IN KAN.ACHA COALS," ZAVODSKAYA LABORATORIYA, 52(10), PP. 31.35, 1986.

10. PROVANCE, D. R., GLASCOCK, M. D., ALPLIN, K. R., "INAA OF COALS FROM THE MIDWESTERN USA. 1. CHEMICAL COMPOSITION," JOURNAL OF RADIOANALYTICAL AND NUCLEAR CHEMISTRY, 140(2), PP. 271-283, 1990.

11. RASMUSSEN, N. C., THE POTENTIAL OF PROMPT ACTIVATION ANALYSIS IN INDUSTRIAL PROCESSING," PROCEEDINGS OF THE ANALYSIS INSTRUMENTATION SYMPOSIUM, 15(7), PP. 186-192, 1969.

12. SIMON, L, HALLY, J., BARCALOVA, L., "RADIOMETRICAL DETERMINATION OF TOTAL SULFUR IN BROWN COAL," ACTA MONTATANA, 59, PP: 59-80, 1982.

13. SIMON, L., HALLY, J., SVEJDA, J., SOK, V., BARCALOVA, L., "TOTAL SULPHUR IN COAL IN THE MINING ENTERPRISE DOLY LEZAKY NEAR MOST (NORTH BOHEMIAN BROWN-COAL DISTRICT)," ACTA MONTATANA, 64, PP. 33-58, 1983. 
14. SIMON, L., HALLY, J., BARCALOVA, L., "SIMULTANEOUS DETERMINATION OF PYAITIC SULFUR AND ASH IN COAL," CZECH PATENT, CS 232406 B1, 5 P., 1986.

15. STARCHIK, L. P., GRABOV, P. I., MIKHAILOV, G. I., POTOPOV, A. B., "RAPID ANALYSIS OF COAL SULFUR AND ASH, "KOKS I KHIMIYA, 12, PP. 42-44, 1984.

16. TASSICKER, O., KARLSON, F., RUBY, J., BROWN, D., "CONTINUOUS NUCLEAR ANALYZER OF COAL FOR IMPROVED COMBUSTION CONTROL," PROCEEDINGS OF THE AMERICAN POWER CONFERENCE, 44, PP. 293-298, 1982.

17. TRENTACOSTA, S., YURKO, J., "MONROE POWER PLANT SULFUR METER EVALUATION," PROCEEDINGS OF THE AMERICAN POWER CONFERENCE., 49, PP. 64·70, 1987.

18. UNDERWOOD, M. C., PETLER, J. S., "HIGH RESOLUTION PROMPT SPECTROSCOPY $(n, y)$ USING A DOWN HOLE LOGGING TOOL," JOURNAL OF RADIOANALYTICAL AND NUCLEAR CHEMISTRY, 114(2), PP. 379-385, 1987.

19. VOURVOPOULOS, G., WOMBLE, P. C., "ON-LINE SULFUR DETERMINATION IN COAL WITH PROMPT GAMMA NEUTRON ACTIVATION, " NUCLEAR INSTRUMENTATION METHODS IN PHYSICAL RESEARCH, B36, PP. 200-205, 1989.

\section{XAFS: XANES, EXAFS}

Several research groups have developed and used an instrumental method to investigate the molecular structure of organic sulfur in coal and to quantify the functional forms of organic sulfur. In early work, Hurley and White (See X-ray fluorescence reference 9) showed the dependence of the sulfur $K_{B}$ peak position on the form of sulfur and attempted to quantify pyritic, sulfatic, and organic sulfur. $X$-ray absorption fine structure (XAFS) spectroscopy determines the electronic structure and atomic environment of an element by examination of the fine structure of an $x$ ray absorption edge.

The region within about 20 to 50 electron volts of the absorption edge is called the $x$ ray absorption near-edge spectra (XANES). Structure in this area is derived primarily from photoelectron transitions to vacant levels and low-energy scattering resonance. The XANES spectra is, thus, quite sensitive to the detailed nature of the bonding of the sulfur atom and can be used to identify different compounds or 
types of binding. The extended $x$-ray absorption fine structure or EXAFS is the oscillatory structure that begins at 30.50 electron volts above the edge and extends to about 500 to 1000 electron volts. These oscillations arise from interference between the outgoing and backscattered photoelectron wave functions. Fourier transform analyses of these yields a radial structure function from which interatomic distances and coordination numbers for the atomic neighbors of the sulfur atom can be determined.

Essentially all work using these phenomena for analyses has been performed by Gorbaty and co-workers $(2-8,17,18)$ and Huffman and co-workers $(9-14,19-21)$. Gorbaty developed a differential treatment of the XANES spectra and have shown that the amplitude of certain features in the third derivative are proportional to the relative amounts of sulfidic and thiophenic sulfur. Huffman adopted a least-squares approach to fit the XANES spectra directly with a series of s-p transition peaks, resonance scattering peaks, and functions representing the transition of photoelectrons to the continuum. They claim that the least-squares analysis method is capable of determining all major functional forms of sulfur.

Although each sulfur form has a characteristic peak in the XAFS spectrum, some structures overlap to such an extent that they are not presently resolvable. In addition, significant correction factors are needed to convert from raw intensities to weight fraction measurements. Despite these limitations, the results of these techniques appear quite impressive, but because high-intensity synchrotron $x$-ray source is required, it is unlikely that these procedures will be widely used.

1. BROWN, J. R., KASRAI, M., BANCROFT, G. M., TAN, K. H., CHEN, J-M., "DIRECT IDENTIFICATION OF ORGANIC SULFUR SPECIES IN RASA COAL FROM SULFUR L.EDGEX. RAY ABSORPTION NEAR EDGE SPECTRA," KENTUCKY CONFERENCE, 1991.

2. CHATTERWEE, K., STOCK, L. M., GORBATY, M. L., GEORGE, G. N., KELEMEN, S. R., "XANES EVIDENCE FOR SELECTIVE ORGANIC SULFUR REMOVAL FROM ILLINOIS NO. 6 COAL," ENERGY AND FUELS, 5, PP. 771.773, 1991.

3. GEORGE, G. N, GORBATY, M. L., KELEMEN, S. R., SANSONE, M., "DIRECT DETERMINATION AND QUANTIFICATION OF SULFUR FORMS IN COALS FROM THE ARGONNE PREMIUM SAMPLE PROGRAM," ENERGY AND FUELS, 5, PP. 93-97, 1991. 
4. GORBATY, M. L., GEORGE, G. N., KELEMEN, S. R., SANSONE, M., "DIRECT DETERMINATION AND QUANTIFICATION OF SULFUR FORMS IN COALS," PROCEEDINGS: FIRST INTERNATIONAL SYMPOSIUM ON THE BIOLOGICAL PROCESSING OF COAL (EPRI GS-6970), PP. 1-35 - 1.41, 1990.

5. GORBATY, M. L., GEORGE, G. N., KELEMEN, S. R., "DIRECT DETERMINATION AND QUANTIFICATION OF SULFUR FORMS IN HEAVY PETROLEUM AND COALS. PART II: THE SULFUR K EDGE X-RAY ABSORPTION SPECTROSCOPY APPROACH, " AMERICAN CHEMICAL SOCIETY DIVISION OF FUEL CHEMISTRY PREPRINTS, 34(3), PP. 738-744, 1989.

6. GORBATY, M. L., GEORGE, G. N., KELEMEN, S. R., "CHEMISTRY OF ORGANICALLY BOUND SULFUR FORMS DURING THE MILD OXIDATION OF COAL," FUEL, 69, PP. 1065-1067, 1990.

7. GORBATY, M. L., GEORGE, G. N., KELEMEN, S. R., "DIRECT DETERMINATION AND QUANTIFICATION OF SULFUR FORMS IN HEAVY PETROLEUM AND COALS: 2. THE SULFUR KEDGE X-RAY ABSORPTION SPECTROSCOPY APPROACH," FUEL, 69, PP. 945-949, 1990.

8. GORBATY, M. L., GEORGE, G. N., KELEMEN, S. R., SANSONE, M., "DIRECT DETERMINATION AND QUANTIFICATION OF SULFUR FORMS IN COALS FROM THE ARGONNE PREMIUM SAMPLE BANK," AMERICAN CHEMICAL SOCIETY DIVISION OF FUEL CHEMISTRY PREPRINTS, 35(3), PP. 779-783, 1990.

9. HUFFMAN, G. P., HUGGINS, F. E., MITRA, S., SHAH, N., LYTLE, F. W., GREEGOR, R. B., "FORMS AND OCCURRENCE OF SULFUR AND CHLORINE IN COAL," PHYSICA B, 158(1-3), PP. 225-226, 1989.

10. HUFFMAN, G. P., HUGGINS, F. E., MITRA, S., SHAN, N., PUGMIRE, R. J., DAVIS, B., LYTLE, F. W., GREEGOR, R. B., "INVESTIGATION OF THE MOLECULAR STRUCTURE OF ORGANIC SULFUR IN COAL BY XAFS SPECTROSCOPY," ENERGY AND FUELS, 3, PP. 200-205, 1989.

11. HUFFMAN, G. P., HUGGINS, F. E., SHAN, N., BHATTACHARYYA, D., PUGMIRE, R. J., DAVIS, B., LYTLE, F. W., GREEGOR, R. B., "EXAFS INVESTIGATION OF ORGANIC SULFUR IN COAL," AMERICAN CHEMICAL SOCIETY DIVISION OF FUEL CHEMISTRY PREPRINTS, 33(1), PP. 201-208, 1988.

12. HUFFMAN, G. P., MITRA, S., HUGGINS, F. E., SHAH, N., VAIDYA, S., LU, F., "QUANTITATIVE ANALYSIS OF ALL MAJOR FORMS OF SULFUR IN COAL BY X-RAY ABSORPTION FINE STRUCTURE SPECTROSCOPY," ENERGY AND FUELS, 5, PP. 574-581, 1991. 
13. HUFFMAN, G.P., SHAH, N., TAGHIEI, M., LU, F., HUGGINS, F. E., "QUANTITATIVE ANALYSIS OF SULFUR FUNCTIONAL FORMS AND REACTIONS BY XAFS SPECTROSCOPY," AMERICAN CHEMICAL SOCIETY DIVISION OF FUEL CHEMISTRY PREPRINTS, 36(3), PP. 1204-1212, 1991.

14. HUGGINS, F. E., SHAH, N., HUFFMAN, G. P., "COMPREHENSIVE INVESTIGATION OF INORGANIC AND SULFUR SPECIES IN COAL, FINAL REPORT," REPORT NO. EPRI-EARIGS. 7322, EPRI, PALO ALTO, CALIFORNIA, 111 P., 1991.

15. KASRAI, M., BROWN, J. R., BANCROFT, G. M., TAN, K. H., CHEN, J-M., "CHARACTERIZATION OF SULFUR IN COAL FROM SULFUR L-EDGE XANES SPECTRA," FUEL, 69, PP. 411-414, 1990.

16. KASRAI, M., BROWN, J. R., YIN, Z., BANCROFT, G. M., TAN, K. H., "SPECIATION OF ORGANIC SULFUR AND ITS OXIDATION PRODUCTS IN COAL FROM L-EDGE X-RAY ABSORPTION SPECTROSCOPY, " KENTUCKY CONFERENCE, 1991.

17. KELEMEN, S. R, GEORGE, G. N., GORBATY, M. L., "DIRECT DETERMINATION AND QUANTIFICATION OF ORGANIC SULFUR FORMS BY X-RAY PHOTOELECTRON SPECTROSCOPY (XPS) AND SULFUR K-EDGE ABSORPTION SPECTROSCOPY, " FUEL PROCESSING TECHNOLOGY, 24, PP. 425-429, 1990.

18. KELEMEN, S. R., GORBATY, M. L., GEORGE, G. N., KWIATEK, P. J., SANSONE, M., "THERMAL REACTIVITY OF SULFUR FORMS IN COAL," FUEL, 70, PP. 396-402, 1991.

19. MEHDI, M. T., HUGGINS, F. E., SHAH, N., HUFFMAN, G. P., "IN SITU XAFS STUDIES OF SULFUR IN COAL DURING HIGH TEMPEHATURE PYROLYSIS AND OXIDATION, " AMERICAN CHEMICAL SOCIETY DIVISION OF FUEL CHEMISTRY PREPRINTS, 36(2), PP. 757-764, 1991.

20. MITRA, S., HUGGINS, F. E., SHAH, N., HUFFMAN, G. P., "INVESTIGATION OF ORGANIC SULFUR STRUCTURE AS A FUNCTION OF COAL RANK," AMERICAN CHEMICAL SOCIETY DIVISION OF FUEL CHEMISTRY PREPRINTS, 35(2), PP. 364-369, 1990.

21. SHAH, N., HUGGINS, F., MITRA, S., TAGHIEI, M., LU, F., HUFFMAN, G., "XAFS INVESTIGATION OF THE MOLECULAR FORMS OF ORGANIC SULFUR IN COAL," FIFTEENTH ANNUAL EPRI CONFERENCE ON FUEL SCIENCE, PALO ALTO, CALIFORNIA, 7 P., JUNE 19 $21,1990$. 
22. SPIRO, C. L., WONG, J., LYTLE, F. W., GREEGOR, R. B., MAYLOTTE, D. H., LAMSON, S. H., "X-RAY ABSORPTION SPECTROSCOPIC INVESTIGATION OF SULFUR SITES IN COAL: ORGANIC SULFUR IDENTIFICATION," SCIENCE, 226, PP. 48-50, 1984.

23. STOCK, L. M., WOLNY, R., BAL, B., "SULFUR DISTRIBUTION IN AMERICAN BITUMINOUS COALS, " ENERGY AND FUELS, 3(6), PP. 652-661, 1989.

24. WALDO, G. S., MULLINS, O. C., PENNER-HAHN, J. E., CRAMER, S. P., "DETERMINATION OF THE CHEMICAL ENVIRONMENT OF SULPHUR IN PETROLEUM ASPHALTENES BY X-RAY ABSORPTION SPECTROSCOPY," FUEL, 61, PP. 53-57, 1982. 


\section{MOSSBAUER SPECTROSCOPY}

The Mossbauer effect involves the recoiliess resonant emission and absorption of gamma rays by certain nuclei. Potassium and iron are the only nuclei commonly present in coal that exhibit the Mossbauer effect. The potassium spectra are difficult to obtain and reveal little data of interest. Thus, in its application to coal, Mossbauer spectroscopy provides a means for determining the presence of iron pyrite (1,3$5,7,9-11,13-17)$ as well as other iron containing compounds such as sulfates, oxides, hydroxides, and clays $(6-8,12)$. At the present, however, the data obtained for forms of sulfur are generally less reliable than those from ASTM procedures. This has led to attempts to combine Mossbauer with other techniques $(2,6)$.

1. AUDLEY, G. J., PYNE, G. S., TRICKER, M. J., CRANSHAW, T. E., LAUNDY, B. J., "A NEW APPROACH TO THE DETERMINATION OF PYRITE IN COALS BY MOSSBAUER SPECTROSCOPY," FUEL, 65(8), PP. 1103-1107, 1986.

2. BHAN, C., CHATURVEDI, S., RAJ, D., NATH, N., "ENERGY DISPERSIVE X-RAY FLUORESCENCE AND MOSSBAUER SPECTROSCOPIC CHARACTERIZATION OF COAL," NUCLEAR GEOPHYSICS, 1(4), PP. 353-356, 1987.

3. CZERW, B., SIKORA, T., "USE OF THE MOSSBAUER EFFECT TO DETERMINE PYRITIC SULFUR IN COAL," PRZEGLAD GORNICZY, 42(10), PP. 331-335, 1976.

4. DOVZHENKO, N. F., SMOILOVSKII, A. N., CHERNYSHOV, YU. A., "DETERMINATION OF THE PERCENTAGE CONTENT OF PYRITE IN DONETS COALS BY NUCLEAR GAMMA RESONANCE," KHIMIYA TVERDOGO TOPLIVA, 11(5), PP. 73-74, 1977.

5. EVANS, B. J., KING, H. M., RENTON, J. J., STILLER, A., "THE QUANTITATIVE

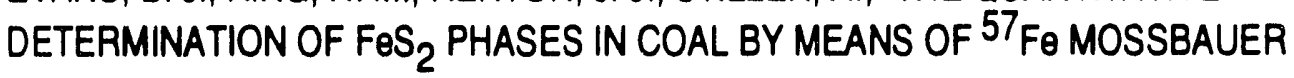
SPECTROSCOPY," HYPERFINE INTERACTIONS, 57, PP. 2187-2194, 1990.

6. GIULIANEW, J., WILLIAMSON, D. L., "SULFUR FORMS DETERMINATION IN COAL USING MICROWAVE DISCHARGE ACTIVATED OXYGEN AND MOSSBAUER SPECTROSCOPY," ATOMIC AND NUCLEAR RESEARCH METHODS IN FOSSIL ENERGY RESEARCH, PP. 443458.

7. HUFFMAN, G. P., HUGGINS, F. E., "MOSSBAUER STUDIES OF COAL AND COKE: QUANTITATIVE PHASE IDENTIFICATION AND DIRECT DETERMINATION OF PYRITIC AND IRON SULPHIDE SULPHUR CONTENT," FUEL, 57, PP. 592-604, 1978. 
8. HUGGINS, F. E., HUFFMAN, G. P., "RAPID MOSSBAUER-BASED METHODS FOR THE DETERMINATION OF IRON-BEARING PHASES," JOURNAL OF APPLIED PHYSICS, 55(5), PP. 1404-1409, 1984.

9. JAGGI, N. K., RAO, KALLAKURI R. P. M., "A SIMPLE MOSSBAUER PYRITE METER," FUEL, 58(9), PP. 688-689, 1979.

10. LEVINSON, L. M., "MOSSBAUER EFFECT SPECTROSCOPIC STUDY OF PYRITIC SULFUR IN COAL," AIP CONFERENCE PROCEEDINGS, NO. 70, (CHEMISTRY AND PHYSICS OF COAL UTILIZATION), PP. 209-234, 1980.

11. LEVINSON, L. M., JACOBS, I. S., "MOSSBAUER SPECTROSCOPIC MEASUREMENT OF PYRITE IN COAL," FUEL, 56(4), PP. 453-454, 1977.

12. MICHAEL, P. J., MOSSEY-MIRZII, P., MELSHINNIE, W. R., "MOSSBAUER STUDY OF THE DECOMPOSITION OF IRON-BEARING CLAY MINERALS DURING THE ASHING OF FIVE COALS," FUEL, 7O(1), PP. 119-121, 1991.

13. NETO, H. N., BRISTOTI, A., VASQUES, A., "A SIMPLE METHOD FOR PYRITIC SULFUR DETERMINATION IN COAL, USING MOSSBAUER SPECTROSCOPY," INTERNATIONAL JOURNAL OF MINERAL PROCESSING, 24, PP. 73-80, 1988.

14. SLAUGHTER, W. W., LEVINSON, L, L., "MOSSBAUER EFFECT SPECTROSCOPIC STUDY OF PYRITIC SULFUR IN COAL," EPRI-FP 1228, RESEARCH PROJECT 237-2, FINAL REPORT, OCT., 1979.

15. SMITH, G.V., LIU, J.H., SAPOROSCHENKO, M., "MOSSBAUER SPECTROSCOPIC INVESTIGATION OF IRON SPECIES IN COAL," FUEL, 57, PP. 41-55, 1978.

16. "STRUCTURAL CHARACTERIZATION OF IMPORTANT ELEMENTS IN BIOPROCESSED COAL," PROCEEDINGS: FIRST INTERNATIONAL SYMPOSIUM ON THE BIOLOGICAL PROCESSING OF COAL, (EPRI GS 6970), PP. 1-65, 1990.

17. WILLIAMSON, D. L., GUETTINGER, T. W., DICKERHOOF, D. W., "QUANTITATIVE INVESTIGATIONS OF PYRITE AND COAL," ADVANCES IN CHEMISTRY SERIES, 194, MOSSBAUER SPECTROSCOPY AND ITS CHEMICAL APPLICATIONS, AMERICAN CHEMICAL SOCIETY, WASHINGTON, D. C., PP. 177-208, 1981. 


\section{RADIOACTIVE AND STABLE TRACER TECHNIQUES}

The use of radioactive tracers in analysis basically involves determining a naturally occurring or introduced element based upon its emissions and assuming that nonradioactive isotopes of the same element behave in the same manner. Downey and Kelley $(2,4)$ have applied isotope dilution techniques to the determination of sulfur. Vartolomeev spiked coal with organosulfur compounds containing $S^{35}$ and followed their fate during coking (6). The use of stable isotopes relies on the observation that in some coals, pyritic and organic sulfur have different abundances of naturally occurring isotopes of sulfur. By determining the ratios of these isotopes in sulfate or elemental sulfur in the coal, the mechanism for the formation of these compounds can be determined. Buchanan (1), Hackley (3), Liu (5), and Westgate (7) determined the source of elemental sulfur extracted from coal based upon the relative concentrations of stable isotopes of sulfur.

1. BUCHANAN, D. H., WARFEL, L. C., "PERCHLOROETHYLENE EXTRACTION OF SULFUR AND SULFUR COMPOUNDS FROM COAL," AMERICAN CHEMICAL SOCIETY DIVISION OF FUEL CHEMISTRY PREPRINTS, 35(2), PP. 516-522, 1990.

2. DOWNEY, D., HUSTON, G., "SUBSTOICHIOMETRIC ISOTOPE DILUTION ANALYSIS OF SULFUR IN COAL," ANALYTICAL LETTERS, 16 (A17 \& 18), PP. 1469-1484, 1983.

3. HACKLEY, K. C., BUCHANAN, D. H., COOMBS, K., CHAVEN, C., KRUSE, C. W., "SOLVENT EXTRACTION OF ELEMENTAL SULFUR FROM COAL AND A DETERMINATION OF ITS SOURCE USING STABLE ISOTOPES," FUEL PROCESSING TECHNOLOGY, 24, PP. 431-436, 1990.

4. KELLEY, W. R., PAULSEN, P. J., "PRECISE AND ACCURATE DETERMINATION OF HIGH CONCENTRATIONS OF SULPHUR BY ISOTOPE-DILUTION THERMAL-IONIZATION MASSSPECTROMETRY," TALANTA, 31(12), PP. 1063-1068, 1984.

5. LIU, C., HACKLEY, K., COLEMAN, D., KRUSE, C., "USING STABLE ISOTOPES TO MONITOR FORMS OF SULFUR DURING DESULFURIZATION PROCESSES: A QUICK SCREENING METHOD," FUEL PROCESSING TECHNOLOGY, 15, PP. 377-384, 1987.

6. VARFOLOMEEV, D. F., KHAIRUDINOV, I. R., AKHMETOV, M. M., MUKHAMETZYANOVA, R. M., THE NATURE OF THE SULFUR IN PETROLEUM COKES," SOLID FUEL CHEMISTRY, 18(4), PP. 118-121, 1984. 
7. WESTGATE, L., ANDERSON, T., "EXTRACTION OF VARIOUS FORMS OF SULFUR FROM COAL AND SHALE FOR STABLE SULFUR ISOTOPE ANALYSIS," ANALYTICAL CHEMISTRY, 54, PP. 2136-2139, 1982.

\section{ICP AND ATOMIC ABSORPTION}

Inductively couple plasma/atomic emission spectroscopy (ICP/AES) is capable of simultaneously determining many elements in a single sample. However, it is less applicable to sulfur than to metallic elements. Caroli was able to determine sulfur in coal extracts and digestates by ICP/AES (1). McCurdy determined sulfur directly in coal by ICPIAES by grinding the coal to less than 6 microns and directly nebulizing the slurry into the plasma.

Atomic absorption spectroscopy is not directly applicable to sulfur. Hocking (2) isolated all major sulfur forms in coal and oil shale by extracting the sulfate with $10 \%$ perchloric acid, converting pyrite to $\mathrm{H}_{2} \mathrm{~S}$ with lithium aluminum hydride followed by its oxidation to sulfate with hydrogen peroxide, and oxidizing organic sulfur to sulfate by the "liquid fire" reaction. The isolated sulfates were then converted to barium sulfate, decomposed to barium carbonate, dissolved in $\mathrm{HCl}$ and the barium determined by atomic absorption. Surprisingly, despite the complexity of the method, relatively accurate results were reported.

1. CAROLI, S., MAZZEO, A., LAURENZI, A., SENOFONTE, O., VIOLANTE, N., "DETERMINATION OF SULPHUR IN COAL PRODUCTS BY INDUCTIVE Y Y COUPLED PLASMA ATOMIC EMISSION SPECTROMETRY," JOURNAL OF ANALY'ICAL ATOMIC SPECTROMETRY, 3, PP. 245-248, 1988.

2. HOCKING, T., GULICK, W., "DETERMINATION OF SULFUR FORMS IN NATURAL FUEL MATERIALS BY ATOMIC ABSORPTION SPECTROMETRY OF BARIUM," ANALYTICA CHIMICA ACTA, 151 (1), PP. 195-202, 1983.

3. MCCURDY, D., FRY, R., "RAPID SULFUR DETERMINATION IN BITUMINOUS AND SUBBITUMINOUS COAL BY SLURRY ATOMIZATION INDUCTIVELY COUPLED PLASMA EMISSION SPECTROMETRY," ANALYTICAL CHEMISTRY, 58, PP. 3126-?`32, 1986. 
.40

INFRARED, RAMAN, AND NMR SPECTROSCOPIES

\section{Infrared and Raman Spectroscopies}

Infrared spectroscopy is widely used to characterize mineral species and chemical functionalities in coal, but has too low of detection limits to determine sulfur functionalities in typical coals. Baruah (1) has claimed to observe iron-sulfur bonds in coal, but alternative explanations for the absorbances he uses are possible. Nondispersive infrared detectors (3-5) are widely used in instrumental methods for determining $\mathrm{SO}_{2}$ in gases evolved during coal decomposition. It appears the Raman spectroscopy has not been applied directly to the characterization of sulfur groups in coal but has been applied (2) to the determination of sulfur anions of the types that can be isolated from coal.

1. BARUAH, M., "INFRARED IDENTIFICATION OF THE IRON-SULFUR BOND IN ASSAM COAL," CURRENT SCIENCE, 53(23), 1984.

2. MEYER, B., OSPINA, M., PETER, L. B., "RAMAN SPECTROMETRIC DETERMINATION OF OXYSULFUR ANION IN AQUEOUS SYSTEMS," ANALYTICA CHIMICA ACTA, 117, PP. $301 \cdot$ $311,1980$.

3. LAWRENZ, D. AND G. SITEK, "RAPID HIGH TEMPERATURE COMBUSTION FOR DETERMINING TOTAL SULFUR BY MICROPROCESSOR CONTROLLED INFRARED ABSORPTION," PROCEEDINGS OF THE THIRD INTERNATIONAL COAL TESTING CONFERENCE, LEXINGTON, KENTUCKY, PP. 16-18, OCT. 24-26, 1983.

4. WARNE, S. S., BLOODWORTH, A., MORGAN, D., "THERMOMAGNETOMETRY AND EVOLVED GAS ANALYSIS IN THE IDENTIFICATION OF ORGANIC AND PYRITIC SULPHUR IN COAL AND OIL SHALE," THERMOCHIMICA ACTA, 93, PP. 745-748, 1985.

5. WARNE, S. ST. J., "COAL PROXIMATE ANALYSIS AND PYRITE CONTENTS BY THE TMTTG METHOD. THE PROBLEM OF IRON-BEARING CARBONATES," THERMOCHIMICA ACTA, 87, PP. 353-356, 1985. 


\section{Nuclear Magnetic Resonance Spectroscopy}

Nuclear magnetic resonance (NMR) spectroscopy is generally applicable to liquid samples and to functionalities present at relatively high concentrations. Thus, sulfur33 NMR has been applied almost exclusively to the characterization of liquid fuels. Evans (1) used $S^{33}$ NMR in conjunction with $\mathrm{O}^{17}$ NMR to characterize sulfinyl, sulfonyl, sulfonic acid, and other groups in coal liquids. Ngassoum (3) applied $S^{33}$ and $C^{13}$ NMR to characterize suffur containing groups in petroleum. Rafii (4) used a derivitization technique using $\mathrm{Sn}^{119}$ to characterize sulfur compounds in petroleum.

1. EVANS, S., "OXYGEN-17 AND SULFUR-33 NUCLEAR MAGNETIC RESONANCE SPECTROSCOPY OF ORGANOSULFUR COMPOUNDS," NATO ASI SERIES, SERIES C, 124 (MAGNETIC RESONANCE), PP. 757-766, 1984.

2. FRENCH, D. C., CRUMRINE, D. S., "IMPROVED CORRELATION OF ${ }^{33}$ S CHEMICAL SHIFTS

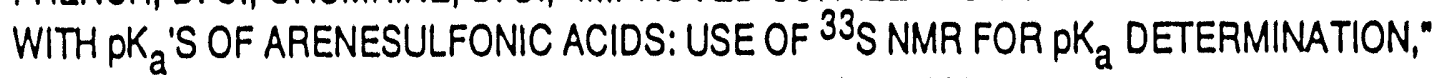
JOURNAL OF ORGANIC CHEMISTRY, 55, PP. 5494-5496, 1990.

3. NGASSOUM, M. B., FAURE, R., RUIZ, J. M., LENA, L., VINCENT, E. J., NEFF, B., "S NMR: A TOOL FOR ANALYSIS OF PETROLEUM OILS," FUEL, 65, PP. 142-143, 1986.

4. RAFII, E., NGASSOUM, M., FAURE, R, FOON, R., LENA, L., METTZGER, J., "STRUCTURAL CHARACTERIZATION OF SULPHUR COMPOUNDS IN PETROLEUM FRACTIONS BY ${ }^{119} \mathrm{~S} n$ NUCLEAR MAGNETIC RESONANCE SPECTROMETRY," FUEL, 70, PP. 132-135, 1991. 


\section{SECONDARY ION MASS SPECTROMETRY}

Secondary ion mass spectrometry (SIMS) generally involves bombarding the surface of a sample with negative oxygen ions causing surface material to be sputtered off. That material is then analyzed using a conventional mass spectrometer. In conjunction with microprobe analysis, fairly narrow beams can be directed towards the surface yielding a profile of elemental composition vs. location. During the sputtering process, surface layers are removed, and thus depth profiling is possible. This appears to be a very powerful technique, but has only been applied sparingly to coal.

1. MARTIN, R. R., MCINTYRE, N. S., MaCPHEE, AYE, K. T., "SECONDARY ION MASS SPECTROMETRY AND X.RAY PHOTOELECTRON SPECTROSCOPY OF DERIVITIZED COAL SURFACES," AMERICAN CHEMICAL SOCIETY DIVISION OF FUEL CHEMISTRY PREPRINTS, 32(1), PP. 154-161, 1987.

2. MCINTYRE, N. S., MARTIN, R. R., CHAUVIN, W. J., WINDER, C. G., BROWN, J. R., MACPHEE, J. A., "STUDIES OF ELEMENTAL DISTRIBUTIONS WITHIN DISCRETE COAL MACERALS: USE OF SECONDARY ION MASS SPECTROMETRY AND X-RAY PHOTOELECTRON SPECTROSCOPY," FUEL, 64, PP. 1705-1712, 1985.

3. WEISE, R. G., JR., MUIR, I. J., FYTE, W., S., "TRACE ELEMENT SITING IN IRON SULFIDES FROM COAL DETERMINED BY SECONDARY ION MASS SPECTROMETRY," ENERGY SOURCES, 12, PP. 252-264, 1990. 


\section{CHROMATOGRAPHIC METHODS}

\section{Gas Chromatography}

Gas chromatography is applicable only to compounds or derivatives of compounds that are volatile. The use of gas chromatography for the determination of sulfurcontaining compounds is enhanced greatly by the existence of the sulfur-specific flame photometric detector (2). Because it is limited to volatile compounds, gas chromatography is applied to the determination of volatile organic compounds isolated from coal by extraction, degradation, or other procedures or to the determination of volatile compounds in liquid or gaseous coal products. Chen, Timpe and White $(2,11-14)$ have determined sulfur-containing compounds extracted from coal. Eglington and lbarra have attempted to correlate the pyrolysis products of coal with its sulfur-containing constituents. Eisenberg, Kong, Nishioka, and Willey $(4,7-9,15)$ have used gas chromatography to characterize sulfur-containing compounds is coal-derived liquid fuels. Hippo and Palmer $(5,10)$ have oxidized coal and used identifications of sulfur-containing products of the oxidation to characterize the sulfur-containing groups originally present in coal macerals.

1. CHEN, K. Y., MOUSSAVI, M., SYCIP, A., "SOLVENT EXTRACTION OF SULFUR FROM MARINE SEDIMENT AND ITS DETERMINATION BY GAS CHROMATOGRAPHY," ENVIRONMENTAL SCIENCE AND TECHNOLOGY, 7(10), PP. 948-951, 1973.

2. DARLAGE, L. J., BLOCK, S. S., WEIDNER, J. P., "USE OF A FLAME PHOTOMETRIC DETECTOR FOR THE ANALYSIS OF COAL SULFUR," JOURNAL OF CHROMATOGRAPHIC SCIENCE, 11(5), PP. 272-274, 1973.

3. EGUNTON, T. I., DAMSTE, J. S. S., KOHNEN, E. L., DE LEEUW, J. W., "RAPID ESTIMATION OF THE ORGANIC SULFUR CONTENT OF KEROGENS, COALS AND ASPHALTENES BY PYROLYSIS-GAS CHROMATOGRAPHY," FUEL, 69(11), PP. 1394-1404, 1990.

4. EISENBERG, W. C., SOLOMON, I. J., "FORMATION OF BENZENE POLYCARBOXYLIC ACIDS IN THE OXYGEN OXIDATION OF SOLID BY-PRODUCTS FROM COAL CONVERSION PROCESSES (CCP) IN AN ALKALINE MEDIUM," FUEL, 56(2), 1977.

5. HIPPO, E. J., PALMER, S., CRELLING, J., KRUGE, M., WHITE, C., "ORGANIC SULFUR SPECIES DISTRIBUTION IN BITUMINOUS AND LOW RANK COALS," PROCEEDINGS: FIRST INTERNATIONAL SYMPOSIUM ON THE BIOLOGICAL PROCESSING OF COAL, (EPRI GS 6970), PP. 1-17-1-31, 1990. 
6. IBARRA, J., MIRANDA, J., PEREZ, A., "PRODUCT DISTRIBUTION AND SULFUR FORMS IN THE LOW TEMPERATURE PYROLYSIS OF A SPANISH SUBBITUMINOUS COAL," FUEL PROCESSING TECHNOLOGY, 15, PP. 31-43, 1987.

7. KONG, R. C., LEE, M. L., IWAO, M., TOMINAGA, Y., PRATAP, R., THOMPSON, R. D., CASTLE, R. N., "DETERMINATION OF SULPHUR HETEROCYCLES IN SELECTED SYNFUELS," FUEL, 63(5), PP. 702-708, 1984.

8. NISHIOKA, M., LEE, M. L., CASTLE, R. N., "SULPHUR HETEROCYCLES IN COAL-DERIVED PRODUCTS," FUEL, 65, PP. 390-396, 1986.

9. NISHIOKA, M., LEE, M. L., "DETERMINATION OF HYDROXYLATED THIOPHENIC COMPOUNDS IN A COAL LIQUID," ANALYTICAL CHEMISTRY, 57, PP. 1327·1330, 1985.

10. PALMER, S. R., HIPPO, E. J., KRAGE, M. A., CRELLING, J. C., "CHARACTERIZATION OF ORGANIC SULFUR COMPOUNDS IN COAL AND COAL MACERALS," GEOCHEMISTRY OF SULFUR IN FOSSIL FUELS, ACS SYMPOSIUM SERIES NC. 429, ORR, W. L., WHITE, C. M., EDS., AMERICAN CHEMICAL SOCIETY, WASHINGTON, D. C., PP. 296-315, 1990.

11. TIMPE, R. C., LOUIE, P. K. K., MILLER, D. J., HAWTHORNE, S. B., "DETERMINATION OF "ORGANIC" SULFUR SPECIES IN COAL BY SUPERCRITICAL FLUID EXTRACTION," PROCEEDINGS OF THE EIGHTH ANNUAL INTERNATIONAL PITTSBURGH COAL CONFERENCE, PP. 63-68, 1991.

12. WHITE, A., WITTINGHAM, J., "ULTIMATE ANALYSIS OF COALS AND COKES USING INSTRUMENTAL TECHNIQUES," FUEL, 62(9), PP. 1058-1061, 1983.

13. WHITE, C. M., LEE, M. L., "IDENTIFICATION AND GEOCHEMICAL SIGNIFICANCE OF SOME AROMATIC COMPONENTS OF COAL," GEOCHIMICA ET COSMOCHIMICA ACTA, 44, PP. $1825-1832,1980$.

14. WHITE, C., DOUGLAS, L., PERRY, M., SCHMIDT, "CHARACTERIZATION OF EXTRACTABLE ORGANOSULFUR CONSTITUENTS FROM BEVIER SEAM COAL," ENERGY AND FUELS, 1 , PP. 222-226, 1987.

15. WILLEY, C., IWAO, M., CASTLE, R. N., LEE, M. L., "DETERMINATION OF SULFUR HETEROCYCLES IN COAL LIQUIDS AND SHALE OILS," ANALYTICAL CHEMISTRY, 53, PP. $400-407,1981$. 


\section{Llquid and lon Chromatography}

Liquid chromatography is applicable to non-volatile or thermally labile compounds that cannot be separated by gas chromatography. Nishioka (9) has used a variation of liquid chromatography, known as ligand-exchange, to selectively isolate sulfurcontaining heterocylic compounds from coal liquids. Miller (6) has used another form of liquid chromatography, known as electrophoresis, to the separation of pyrite. Ion chromatography $(I C)$ is applicable for the rapid determination of anions in aqueous solutions. Coal can be leached with aqueous solvents, and ion chromatography then used to determine soluble anions. Or, coal can be decomposed and the total chlorine, nitrogen, sulfur, and phosphorus content of the coal determined in an aqueous solution of the decomposition products. Hona and Matusiewicz $(4,5)$ report good results for the determination of sulfate in coal and ash leachates. Gent, Nadkarni, and Rigin $(3,7,8)$ have reported good results for total sulfur in coal based upon ion chromatographic determination of sulfate in solutions arising from the decomposition of coal. Chriswell and Uddin $(1,10)$ have used ion chromatography to determine sulfur species in streams arising from the chemical cleaning of coal.

1. CHRISWELL, C. D., MROCH, D. R., MARKUSZEWSKI, R., "DETERMINATION OF TOTAL SULFUR BY ION CHROMATOGRAPHY FOLLOWING PEROXIDE OXIDATION IN SPENT CAUSTIC FROM THE CHEMICAL CLEANING OF COAL," , ANALYTICAL CHEMISTRY, 58, PP. 319.321, 1986.

2. DEAN, J. R., CHIU, N., "EVALUATION OF ION CHROMATOGRAPHY AS A RAPID AND PRECISE ANALYTICAL TOOL FOR THE DETERMINATION OF SULFUR POTENTIAL, NITROGEN, CHLORINE, AND FLUORINE CONTENTS OF LOW SULFUR COALS," INTERNATIONAL COAL TESTING CONFERENCE, LEXINGTON, KENTUCKY, PP. 5-7, SEPTEMBER 11-13, 1984.

3. GENT, C., WILSON, S., "THE DETERMINATION OF SULFUR AND CHLORINE IN COALS AND OIL SHALES USING ION CHROMATOGRAPHY," ANALYTICAL LETTERS, 18 (A6), PP. 729-740, 1985.

4. HONMA, H., SUZUKI, K., YOSHIDA, M., YANASHIMA, H., "DETERMINATION OF CHLORIDE, NITRITE, NITRATE AND SULFATE IONS IN WATER EXTRACT OF COAL BY ION CHROMATOGRAPHY," BUNSEKI KAGAKU, 37, PP. T55-560, 1988. 
5. MATUSIEWICZ, H., NATUSCH, D. F. S., "ION CHROMATOGRAPHIC DETERMINATION OF SOLUBLE ANIONS PRESENT IN COAL FLY ASH LEACHATES," INTERNATIONAL JOURNAL OF ENVIRONMENTAL ANALYTICAL CHEMISTRY, 8, PP. 227-233, 1980.

6. MILLER, K. J., BAKER, A. J., "EVALUATION OF A NOVEL ELECTROPHORETIC SEPARATION METHOD TO REMOVE PYRITIC SULFUR FROM COAL," N.T.IS. PB. REP. NO. 236377/BGA, PP. 1.19, 1974.

7. NADKARNI, R. A., POND, D. M., "APPLICATIONS OF ION CHROMATOGRAPHY FOR DETERMINATION OF SELECTED ELEMENTS IN COAL AND OIL SHALE," ANALYTICA CHIMICA ACTA, 146, PP. 261-266, 1983.

8. NISHIOKA, M., CAMPBELL, R. M., LEE, M. L., CASTLE, R. N., "ISOLATION OF SULPHUR HETEROCYCLES FROM PETROLEUM AND COAL-DERIVED MATERIALS BY LIGAND EXCHANGE CHROMATOGRAPHY," FUEL, 65, PP. 270-273, 1986.

9. RIGIN, V.,"ION CHROMATOGRAPHIC DETERMINATION OF HALOGENS, NITROGEN, PHOSPHORUS, AND SULFUR IN FOSSIL COAL," ZEITSCHAIFT FUR ANALYTISCHE CHEMIE, 42(6), PP. 1073-1076, 1987.

10. UDOIN, Z., MARKUSZEWSKI, R., JOHNSON, D. C., "OETERMINATION OF INORGANIC SULFUR SPECIES IN HIGHLY ALKALINE SOLUTIONS BY LIQUID CHROMATOGRAPHY WITH POLAROGRAPHIC DETECTION," ANALYTICA CHIMICA ACTA, 200, PP. 115.129, 1987. 
$.47 \cdot$

\section{DETERMINATION OF SULFUR BY METHODS BASED UPON COMBUSTION AND PYROLYSIS}

\section{Oxyoen Flagk Combustion}

Combustion in an oxygen flask (Schoeniger flask) provides a very rapid and convenient method for complete conversion of sulfur in coal samples to sulfate. In this method a sample of coal is folded in a filter paper, that paper is retained in a platinum grid attached to the stopper of the flask, a small volume of dilute (approximately 15\%) hydrogen peroxide is placed in the flask, the flask is filled with oxygen, the filter paper is ignited, the stopper is inserted, the flask is inverted, and the sample burns in the oxygen atmosphere for a few seconds. Sulfur in the coal is converted into $\mathrm{SO}_{2}$, dissolves in the peroxide and is oxidized to sulfate, and is then rinsed from the flask with distilled water. The sulfate is then determined by conventional procedures.

Ahmed (2) estimated the sulfur content based upon the pH of the solution arising from the combustion of coal in an oxygen flask. In other work, Ahmed added excess barium perchlorate to solutions and back-titrated the free barium with sulfuric acid $(1,3,4)$. Ion chromatographic, gravimetric, turbidimetric, and other procedures are also applicable to determining sulfate in solutions arising from oxygen-bomb degradations of coal (5-7). When ion chromatography is used to determine sulfate, the fluoride, chloride, nitrate, nitrite, phosphate, and other anions are determined simultaneously. In the unreported work performed at the Ames Laboratory, an attempt was made to determine sulfur in chemically cleaned coal samples using oxygen flask combustion followed by ion chromatography. The results of those attempts were unsatisiactory because the level of sulfur in the filter paper was very high relative to the very low levels of sulfur in the treated coal.

1. AHMED, S. M., WHALLEY, B. J. P., "ANALYSIS OF TOTAL SULPHUR IN CANADIAN COALS BY A MODIFIED OXYGEN-FLASK METHOD USING ARSENAZO (III), " FUEL, 51(3), PP. 190-193, 1971.

2. AHMED, S. M., WHALLEY, B. J. P., "A PH FINISH TO THE OXYGEN-FLASK METHOD FOR ANALYZING TOTAL SULPHUR IN COAL," FUEL, 53(1), PP. 61-62, 1973.

3. AHMED, S. M., WHALLEY, B. J. P., "THE OXYGEN-FLASK METHOD OF DETERMINING TOTAL SULFUR IN COAL," ANALYTICAL METHODS FOR COAL AND COAL PRODUCTS, VOLUMEI, C. KARR, JR., ED., ACADEMIC PRESS, NEW YORK, PP. 263-277, 1978. 
4. AHMED, S. M., WHALLEY, B. J. P, "THE USE OF ARSENAZO (III) IN THE DETERMINATION OF TOTAL SULPHUR IN COAL BY THE OXYGEN-FLASK METHOD," FUEL, 48(2), PP. 217-219, 1969.

5. HOZUMI, K., UMEMOTO, K., "MODIFIED MICRODETERMINATION OF SULFATE ION: ITS APPLICATION TO FLASK COMBUSTION FOR ORGANIC SULFUR," MICROCHEMICAL JOURNAL, 12, PP. 46-54, 1967.

6. MIROSHINA, V. P., EGOROVA, T. I., "SIMULTANEOUS DETERMINATION OF HALOGEN AND SULFUR IN ORGANIC COMPOUNDS," ZAVODSKAYA LABORATORIYA, 50(3), PP. 14-15, 1984.

7. RATCLIFFE, D. B., CUNNINGHAM, A. T. S., "THE SEMI-MICRO DETERMINATION OF TOTAL SULPHUR IN COAL BY THE OXYGEN FLASK METHOD," FUEL, 47(2), PP. 89.92, 1968.

\section{High-Temperature Combustion Techniques}

A large number of high-temperature combustion methods have been described for determining the total sulfur content of coal. The methods are basically similar and differ only in the type of furnace used for combustion and the technique used for determining the evolved sulfur. In a typical procedure, coal is burned in a tube furnace under an oxygen atmosphere, with or without a catalyst, at temperature of $1000^{\circ} \mathrm{C}$ to $1500^{\circ} \mathrm{C}$ and the amount of sulfur dioxide evolved is determined. Several procedures have been used for determining the sulfur dioxide evolved or for determining the sulfate resulting from oxidation of the evolved sulfur dioxide. Acidbase titration (corrected for chlorine), iodimentric titrations, non-dispersive infrared analysis, and precipitation titrations using barium chloride as the titrant are the most common methods. Regardless of the exact combustion conditions or the method of analysis for the evolved sulfur dioxide, results invariably compare very favorably with those obtained by the ASTM eschka fusion method. LECO and Fisher (described below) sell automated instruments employing high-temperature combustion for total sulfur.

1. ARAI, S., KOSEKI, K., KAMEGAYA, H., KOBAYASHI, H., HASUDA, T., OI, E., YANAGISAWA, Y., IWASAKI, J., "RAPID MEASUREMENT OF ASH AND COMBUSTIBLE SULPHUR IN COAL WITH AN INFRARED FURNACE," NIPPON KOGYO KAISHI, 99(1147), PP. 860-862, 1983. 
2. DRAGUSIN, I., GAVRILIUC, A., "RAPID MICRO METHOD FOR THE VOLUMETRIC DETERMINATION OF SULFUR IN COAL AND PETROLEUM PRODUCTS," REVUE ROUMAINE DECHIMIE, 12, PP. 1239-1243, 1967.

3. FINCH, J., IVES-ROHDE, M., "RAPID AND SIMPLE DETERMINATION BY COMBUSTION OF TOTAL SULPHUR IN COAL," FUEL, 59(9), PP. 654-658, 1980.

4. IVANOV, Y., "RAPID ANALYSIS OF SULFUR IN SOLID FUEL," TEPLEONERGETIKA, (5), 27, PP. $39-42,1980$.

5. IVANOV, Y., PREOBRAZHENSKII, V., "METROLOGICAL CHARACTERISTICS OF RAPID ANALYZERS FOR SULFUR IN SOLID FUEL," TEPLEONERGETIKA, 28(5), PP. 70-72, 1981.

6. KALANDADZE, N. D., "IMPROVEMENT OF THE RAPID METHOD FOR SUIFUR DETERMINATION IN COALS," IZV. AKAD. NAUK GRUZ. SSR., SER. KH!!M., 12(4), PP. $252-$ 255.

7. KELEMEN, S. R., GORBATY, M. L., GEORGE, G. N., KWIATEK, P. J., SANSONE, M., "THERMAL REACTIVITY OF SULFUR FORMS IN COAL," FUEL, 70, PP. 396-402, 1991.

8. KLOSE, V. E., LANGE, G., KALTOFEN, E., "COMPARATIVE STUDY FOR DETERMINING TOTAL SULFUR IN SOLID FUELS," FREIBERGLER FORSCHUNGSHEFTE, 534, PP. 125-134, 1974.

9. LADRACH, W., VAN DER LAARSE, J. D., "THE DETERMINATION OF TOTAL SULPHUR IN COAL BY A SEMI-MICRO TUBE-COMBUSTION METHOD," ANALYTICA CHIMICA ACTA, 94, PP. 213-216, 1977.

10. LAWRENZ, D. AND G. SITEK, "RAPID HIGH TEMPERATURE COMBUSTION FOR DETERMINING TOTAL SULFUR BY MICROPROCESSOR CONTROULD INFRARED ABSORPTION," PROCEEDINGS OF THE THIRD INTERNATIONAL COAL TESTING CONFERENCE, LEXINGTON, KENTUCKY, PP. 16-18, OCT. 24-26, 1983.

11. MORGANROTH, W., "HIGH TEMPERATURE COMBUSTION TUBE METHOD FOR THE ANALYSIS OF SULFUR IN COAL," PROCEEDINGS OF THE THIRD INTERNATIONAL COAL TESTING CONFERENCE, LOUISVILLE, KENTUCKY, PP. 23-25, 1983. 
12. NELSON, H. W., SNOW, R. D., KEYES, D. B., "OXIDATION OF PYRITIC SULFUR IN BITUMINOUS COAL," INDUSTRIAL AND ENGINEERING CHEMISTRY, 25(12), PP. 1355-1358, 1933.

13. PARIS, B., "DIRECT DETERMINATION OF ORGANIC SULFUR IN RAW COALS," AMERICAN CHEMICAL SOCIETY DIVISION OF FUEL CHEMISTRY PREPRINTS, 22(5), PP. 22, 1977.

14. POPOV, V. A., ANDRONOVA, N. I., TIKHONOV, I. A., PICHUGIN, V. Y., "DETERMINING TOTAL SULFUR IN COAL AND COKE," KOKS I KHIMIYA, 12, PP. 17-20, 1981.

15. RICE-JONES, W. G., "SULFUR IN ORES, CONCENTRATORS, AND OTHER METALLURGICAL SAMPLES," ANALYTICAL CHEMISTRY, 25, PP. 1383-1385, 1953.

16. THURAUF, V. W., ASSENMACHER, H., "RAPID DETERMINATION OF THE TOTAL SULFUR CONTENT OF SOLID FUELS," BRENSTOFF-CHEMIE, 48(7), PP. 206-207, 1967.

17. VAN GRONDELLE, M. C., ZEEN, P. J., "COULOMETRIC DETERMINATION OF TOTAL SULFUR IN ORGANIC AND INORGANIC MATERIALS AFTER A TUNGSTEN TRIOXIDE QUARTZ TUBE DECOMPOSITION METHOD," ANALYTICA CHIMICA ACTA, 116, PP. 335-343, 1980.

18. WALLACE, L. D., KOHLENBERGER, D. W., JOYCE, R. J., MOORE, R. T., RIDDLE, M. E., MCNULTY, J. A., "COMPARISON OF OXIDATIVE AND REDUCTIVE METHODS FOR THE MICROCOULOMETRIC DETERMINATIONS OF SULFUR IN HYDROCARBONS," ANALYTICAL CHEMISTRY, 42(3), PP. 387-394, 1970.

\section{Using LECO or Fisher Analyzers}

Fisher Scientific and LECO both offer instruments usable for the determination of total sulfur in coal. In both cases coal is burned in an oxygen atmosphere, usually with a vanadium pentoxide catalyst, and the sulfur dioxide evolved is then determined. LECO instruments have employed both an iodometric and a nondispersive infrared detector for the determination of sulfur dioxide. The Fisher instrument employs an iodometric titration in which the titrant is generated electrochemically. These automated instruments provide results faster, those results are generally more reproducible, and these techniques are less expensive than other ASTM procedures. However, any component of the coal sample that could alter the $\mathrm{SO}_{2} / \mathrm{SO}_{3}$ ratio could lead to erroneous results in instruments using 
the IR detector. And, the iodometric titration results could be affected by components in the coal that form reducing agents upon combustion. High levels of chlorine are believed to have adverse effects.

1. GLADNEY, E. S., RAYMOND, R., BOWER, N. W., "AN ANALYZER FOR DETERMINATION OF SULFUR IN COALS AND PEATS," AMERICAN LABORATORY, 17(7), PP. 34-38, 1985.

2. JARMELL, S., "AUTOMATED DETERMINATIONS OF SULFUR IN FOSSIL FUELS," PROCEEDINGS OF THE THIRD COAL TESTING CONFERENCE, LEXINGTON, KENTUCKY, PP. 19-23, 1983.

3. LAWRENZ, D. AND G. SITEK, "RAPID HIGH TEMPERATURE COMBUSTION FOR DETERMINING TOTAL SULFUR BY MICROPROCESSOR CONTROLLED INFRARED ABSORPTION," PROCEEDINGS OF THE THIRD INTERNATIONAL COAL TESTING CONFERENCE, LEXINGTON, KENTUCKY, PP. 16-18, 1983.

4. WHITE, A., WITTINGHAM, J., "ULTIMATE ANALYSIS OF COALS AND COKES USING INSTRUMENTAL TECHNIQUES," FUEL, 62(9), PP. 1058-1061, 1983.

\section{CAPTO Method}

The controlled atmosphere programmed temperature oxidation (CAPTO) method is still in the development phase, but the results published thus far show that the method provides an excellent means for determining major sulfur forms in coal and also differentiates among some forms of organic sulfur. In this method, coal is mixed with an inert substance and subjected to a programmed temperature oxidation. The sulfur dioxide, water, and carbon dioxide evolved are measured separately as a function of time by Fourier transform infrared (FTIR) spectroscopy to give a thermogram. Distinct peaks proportional to the sulfate, pyrite, and at least two forms of organic sulfur appear in these thermograms. Analyses apparently take several hours to perform and the FTIR detector used is expensive. The time involved and the cost of the instrumentation could lead to high-cost determinations. Current work involves reducing the cost per analysis significantly by performing eight oxidations simultaneously using a single, shared detector.

1. LACOUNT, R., ANDERSON, R., FRIEDMAN, S., BLAWSTEIN, B., "SULPHUR IN COAL BY PROGRAMMED TEMPERATURE OXIDATION," FUEL, 66, PP. 903-913, 1987. 
$-52-$

2. LACOUNT, R., KERN, D., KING, W., LACOUNT, R. JR. MILTZ, D., JR., STEWARD, A., TRULLI, T., WALKER, D., WICKER, R., "ADVANCES IN COAL CHARACTERIZATION BY PROGRAMMED TEMPERATURE OXIDATION," AMERICAN CHEMICAL SOCIETY DIVISION OF FUEL CHEMISTRY PREPRINTS, 33(3), PP. 1217-25, 1991.

3. LACOUNT, R., "DIRECT DETERMINATION OF ORGANIC AND INORGANIC SULPHUR IN COAL BY CONTROLLED OXIDATION," PROCEEDINGS OF THE EIGHTH ANNUAL COAL PREPARATION, UTILIZATION, AND ENVIRONMENTAL CONTROL CONTRACTORS CONFERENCE, PITTSBURGH ENERGY TECHNOLOGY CENTER, PITTSBURGH, PENNSYLVANIA, PP. 515-522, 1992.

\section{Pyrolytic Methods for Determining Sulfur in Coal}

Pyrolytic methods for determining sulfur moieties in coal are basically simple. Coal is heated in an inert atmosphere, the amounts and types of sulfur-containing volatile compounds are determined, and data on the amounts and types of volatile compounds are related to the types of sulfur originally present in the coal. However, the pyrolysis temperature, the rate of heating, the amount of coal, the volume of inert gas, the materials from which the pyrolysis reactors are constructed, and the methods for analysing the products all affect the determined components in the volatile compounds evolved. Thus, this simple procedure, has a multitude of variations. Recent work by Calkin and co-workers $(3,13,14)$ is especially significant in establishing flash pyrolysis at temperatures ranging from $750^{\circ} \mathrm{C}$ to $960^{\circ} \mathrm{C}$ as a technique for the determination of three different forms of organic sulfur in coal. In some of the earliest work, Masciantonio (12) showed in 1966 that during pyrolysis at $625^{\circ} \mathrm{C}$ for 2 hours, evolution of sulfur-containing volatiles from model compounds was related to the structure of those model compounds. Aitken (1) studied the decomposition of thianthrene at $550^{\circ} \mathrm{C}$ and dibenzothiphene at temperatures ranging from $550^{\circ} \mathrm{C}$ to $950^{\circ} \mathrm{C}$. Damst'e (6) pyrolysed samples at $610^{\circ} \mathrm{C}$ for 10 seconds and related the types of organic compounds released from kerogen, asphaltenes and coal to the parent sulfur-containing moieties. Ibarra $(9,10)$ has studied the low-temperature pyrolysis of low-rank Spanish coals. Brown reviewed the pyrolytic methods available as of 1980 (2). Chou, Cleyle, and Lambert $(4,5,11)$ have studied transformations of pyrite during pyrolysis. 
.53

1. AITKEN, J., HEEPS, T., STEEDMAN, W., "ORGANIC SULFUR IN COAL: MODEL COMPOUND STUDIES $\|$ - THE PYROLYSIS OF THIANTHRENE AND DIBENZOTHIOPHENE," FUEL, 47, PP. 353-357, 1968.

2. BROWN, R. F. C., PYROLYTIC METHODS IN ORGANIC CHEMISTRY: APPLICATION OF FLOW AND FLASH VACUUM PYROLYTIC TECHNIQUES, ACADEMIC PRESS, NEW YORK, 1980.

3. CALKINS, W., "INVESTIGATION OF ORGANIC SULFUR-CONTAINING STRUCTURES IN COAL BY FLASH PYROLYSIS EXPERIMENTS," ENERGY \& FUELS, 1(1), PP. 59-64, 1987.

4. CHOU, M. I., LAKE, M. A., GRIFFIN, R. A., "FLASH PYROLYSIS OF COAL COAL MACERALS, AND COAL-DERIVED PYRITE WITH ON-LINE CHARACTERIZATION OF '/OLATILE SULFUR COMPOUNDS," JOURNAL OF ANALYTICAL AND APPLIED PYROLYSIS 13, PP.199-207, 1988.

5. CLEYLE, P. J., CALEY, W. F., STEWART, I., WHITEWAY, S. G., "DECON 'OSITION OF PYRITE AND TRAFPING OF SULPHUR IN A COAL MATRIX DURING PYROLYSIS OF COAL," FUEL, 63, PP. 1579-1582, 1984.

6. DAMSTE, J. S. S., EGLINTON, T.I., DELEEUW, J. W., SCHENCK, P. A., "ORGANIC SULFUR IN MACROMOLECULAR SEDIMENTARY ORGANIC MATTER: I. STRUCTURE AND ORIGIN OF SULPHUR-CONTAINING MOIETIES IN KEROGEN, ASPHALTENES, AND COAL AS REVEALED BY FLASH PYROLYSIS," GEOCHIMICA ET COSMOCHIMICA ACTA, 53, PP. 873-889, 1989.

7. GRYGLEWICZ, G., JASIENKO, S., "SULFUR COMPOUNDS IN COALS WITH HIGH SULFUR CONTENT," PRACE NAUKOWE INSTYTUTU CHEMIII I TECHNOLOG II NAFTY I WEGLA POLITECHNIKI WROCLAWSKIEJ, 48(6), PP. 18-19, 1990.

8. GRYGLEWICZ, G., JASIENKO, S., "SULFUR GROUPS IN THE COKES OBTAINED FROM COALS OF DIFFERENT RANKS," FUEL PROCESSING TECHNOLOGY, 19, PP. 51-59, 1988.

9. IBARRA, J. V., PALACIOS, J. M., GRACIA, M., GANCEDO, J. R., "INFLUENCE OF WEATHERING ON THE SULPHUR REMOVAL FROM COAL BY PYROLYSIS," FUEL PROCESSING TECHNOLOGY, 21, PP. 63-73, 1989.

10. IBARRA, J., MIRANDA, J., PEREZ, A., "PRODUCT DISTRIBUTION AND SULFUR FORMS IN THE LOW TEMPERATURE PYROLYSIS OF A SPANISH SUBBITUMINOUS COAL," FUEL PROCESSING TECHNOLOGY, PP. 15, 31-43, 1987. 
11. LAMBERT, J. M., WALKER, P. L., PERROTTA, A. J., MCCULLOUGH, J. P., BEUTHER, H., "PHYSICAL CHARACTERIZATION AND PRESSURE-TEMPERATURE MICROSCOPY OF THE PYRITE-PYRRHOTITE TRANSFORMATION," FUEL, 62, PP. 1474-1480, 1983.

12. MASCIANTONIO, P.X., WALTER, J. W., "PYROLYSIS OF POLYCYCLIC COMPOUNDS CONTAINING SULFUR," COAL SCIENCE: ADVANCES IN CHEMISTAY SERIES NO .55, ACS, WASHINGTON, D.C., PP. 687.694, 1966.

13. TORRES-ORDONEZ, R. J., CALKINS, W. H., KLEIN, M. T., "DISTRIBUTION OF ORGANICSULFUR-CONTAINING STRUCTURES IN HIGH ORGANIC SULFUR COALS," AMERICAN CHEMICAL SOCIETY SYMPOSIUM SERIES 429: GEOCHEMISTRY OF SULFUR IN FOSSIL FUELS, W. L. ORR, C. M. WHITE, EDS., ACS, WASHINGTON, D. C., PP. 287-295, 1990.

14. TORRES-ORDONEZ, R. J., CALKINS, W. H., KLEIN, M. T., "DISTRIBUTION OF ORGANIC SULFUR IN COALS," PRESENTED AT THE AMERICAN CHEMICAL SOCIETY MEETING, DALLAS, TEXAS, APRIL 9-14, 1989.

\section{Reduction of Sulfur to $\mathrm{H}_{2} \underline{\mathrm{S}}$}

The step-wise reduction of different forms of sulfur to hydrogen sulfide provides a basis for determining forms of sulfur in coal. Attar (1-7) and Majchrowicz (9-11) have done the most extensive work on a procedure for determining the forms of organic sulfur in coal based upon step-wise reduction to hydrogen sulfide. Mason, Purnell, and Wnekowski $(12,15,16)$ have also reported correlations between hydrogen sulfide evolution and forms of sulfur. As applied by Attar, several peaks attributed to different forms of organic sulfur are produced, but all organic sulfur is not reduced to hydrogen sulfide. An independent (ASTM) analysis for total organic sulfur is performed and the difference between the total organic sulfur and the evolved forms is reported as complex thiophenenes. These so-called complex thiophenes often constitute a major fraction of all the organic sulfur in a sample. Because total organic sulfur is determined by difference in the ASTM procedure, and complex thiophenes are determined by difference using the value for total organic sulfur, there is a considerable uncertainty in the values provided by this method for much of the organic sulfur in coal. Peeples $(13,14)$ has proposed an interesting procedure for determining certain forms of organic sulfur in coal. Hyperthermophilic archaebacteria degrade only certain forms of organic sulfur in coal and release hydrogen sulfide. The amount of hydrogen sulfide evolved is, thus, proportional to the concentration of specific forms of organic sulfur in coal. 
1. ATTAR, A., "AN ANALYTICAL METHOD FOR THE EVALUATION OF SULFUR FUNCTIONALITIES IN AMERICAN COALS," DOE/PC/30145-T1, DEPARTMENT OF CHEMICAL ENGINEERING, NORTH CAROLINA STATE UNIVERSITY, RALEIGH, NORTH CAROLINA, 1983.

2. ATTAR, A., "AN ANALYTICAL METHOD FOR THE DETERMINATION OF THE DISTRIBUTION OF SULFUR FUNCTIONAL GROUPS IN AMERICAN COALS," DOE/ET/14306-1. DEPARTMENT OF CHEMICAL ENGINEERING, UNIVERSITY OF HOUSTON, HOUSTON, TEXAS.

3. ATTAR, A., "CHEMISTRY, THERMODYNAMICS AND KINETICS OF REACTIONS OF SULPHUR IN COAL - GAS REACTIONS: A REVIEW," FUEL, 57(4), PP. 201-212, 1978.

4. ATTAR, A., "SULFUR GROUPS IN COAL AND THEIR DETERMINATIONS," ANALYTICAL METHODS FOR COAL AND COAL PRODUCTS, VOLUME III, ACADEMIC PRESS, NEW YORK, C. KARR, JR., ED., 3(56), PP. 585-624, 1979.

5. ATTAR, A., CORCORAN, W. H., "SULFUR COMPOUNDS IN COAL," INDUSTRIAL ENGINEERING CHEMISTRY, 16(2), PP. 168-170, 1977.

6. ATTAR, A., DUPUIS, F., "DATA ON THE DISTRIBUTION OF ORGANIC SULFUR FUNCTIONAL GROUPS IN COAL," AMERICAN CHEMICAL SOCIETY DIVISION OF FUEL CHEMISTRY PREPRINTS, 24(1), 1979.

7. ATTAR, A., DUPUIS, F., "ON THE DISTRIBUTION OF ORGANIC SULFUR FUNCTIONAL GROUPS IN COAL," AMERICAN CHEMICAL SOCIETY DIVISION OF FUEL CHEMISTRY PREPRINTS, 23(2), 1978.

8. BHATIA, S. P., "REMOVAL OF ORGANIC SULPHUR FROM COAL GAS," THE CANADIAN JOURNAL OF CHEMICAL ENGINEERING, 49, PP. 605-610, 1971.

9. CHAO, S., MASON, D., ATTARI, A., "IMPROVED METHODS FOR DETERMINATION OF FERROUS SULFIDES IN COAL CHARS," AMERICAN CHEMICAL SOCIETY DIVISION OF FUEL CHEMISTRY PREPRINTS, 32(4), PP. 214-220, 1987.

10. GADYATSKII, V. G., DIDENKO, V. E., PANCHENKO, V. A., GNEZDILOV, O. V., "FEATURES OF. THE EVOLUTION OF HYDROGEN SULFIDE IN THE THERMAL DECOMPOSITION OF HARD COALS OF DIFFERENT RANKS," KHIMIYA TVERDOGO TOPLIVA, 14(1), PP. 17-20, 1980. 
11. MAJCHROWICZ, B. B., YPERMAN, J., MULLENS, J., VAN POUCKE, L. C., "AUTOMATED POTENTIOMETRIC DETERMINATION OF SULFUR FUNCTIONAL GROUPS IN FOSSIL FUELS," ANALYTICAL CHEMISTRY, 63, PP. 760-763, 1991.

12. MAJCHROWICZ, B. B., YPERMAN, J., MARTENS, H. J., GELAN, J. M., WALLACE, S., JONES, C. J., BAXBY, M., TAYLOR, N., AND BARTLE, K. D., "QUANTIFICATION OF ORGANIC SULFUR CONTAINING FUNCTIONAL GROUPS FOR COAL CONVERSION PROCESSES," FUEL PROCESSING TECHNOLOGY, 24, PP. 195-202, 1990.

13. MAJCHROWICZ, B., YPERMAN, J., REGGERS, G, FRANCOIS, J., GELAN, J., MARTENS, H.J., MULLENS, J., VAN POUCKE, L.C., "CHARACTERIZATION OF ORGANIC SULFUR FUNCTIONAL GROUPS IN COAL BY MEANS OF TEMPERATURE PROGRAMMED REDUCTION," FUEL PROCESSING TECHNOLOGY, 15, PP. 363.76, 1987.

14. MASON, D., CHAO, S., "DETERMINATION OF THE DISTRIBUTION OF ASH, PYRITE, AND BASIC CONSTITUENTS IN COAL PARTICLES," AMERICAN CHEMICAL SOCIETY DIVISION OF FUEL CHEMISTRY PREPRINTS, 32(4), PP. 203-13, 1987.

15. PEeples, T. L., HIROSUe, S., MURALIDHARAN, V., KELLEY, R. M., OLSON, G. J., "COAL SULFUR TRANSFORMATIONS MONITORED BY HYPERTHERMOPHILIC ARCHAEBACTERIA," AMERICAN CHEMICAL SOCIETY DIVISION OF FUEL CHEMISTRY PREPRINTS, 34(3), PP. 907.915, 1990.

16. PEeples, T. L., HIROSUE, S., MURALIDHARAN, V., KELLEY, R. M., OLSON, G. J., "COAL SULFUR TRANSFORMATIONS MONITORED BY HYPERTHERMOPHILIC ARCHAEBACTERIA," FUEL, 70(5), PP. 599-604, 1991.

17. PURNELL, A. L., DOOLAN, K. J., "RAPID DETERMINATION OF FORMS OF SULPHUR IN COAL," FUEL, 62(10), PP. 1107-1110, 1983.

18. WNEKOWSKA, L., "STUDIES ON SULFUR GROUPS IN SOLID FUELS," PRACE GLOWNEGO INSTYTUTU GORNICTWA, SERIA B KOMUNIKAT NR 325, KATOWICE, PP. 3-12, 1963. 
-57 .

\section{THERMAL ANALYSIS}

Thermoanalytical techniques have also been used to examine pyrite in coal.

Differential thermal analysis, which shows exothermic and endothermic occurrences as a sample is heated, has been used to identify pyrite in coal or coal ash $(5,6)$, but has not been used for quantitative analyses. A similar technique, known as differential scanning calorimetry, has been used to quantify the pyrite content of coal by measuring oxidation exotherms as the sample is heated in an oxidizing atmosphere (7). However, additional work is required to assess the accuracy and precision of that approach. Other researchers attempted to use evolved gas analysis to monitor sulfur dioxide evolved from coal samples heated in an oxidizing atmosphere in a thermal analyzer (1). The sulfur dioxide evolution profiles could not adequately distinguish between pyritic and organic sulfur, although the application of peak deconvolution techniques may prove beneficial. In other work, the pyrite content of coal has been determined using a thermoanalytical technique known as thermomagnetometry $(1-3,6,7,10)$. In that procedure, pyrite is determined in less than one hour by measuring the weight change induced with a magnet on $\mathrm{Fe}_{2} \mathrm{O}_{3}$ in coal ash while being reduced to $\mathrm{Fe}^{\mathrm{O}}$ in a hydrogen atmosphere in a thermal analysis system. This technique assumes that all of the $\mathrm{Fe}_{2} \mathrm{O}_{3}$ in the coal ash was derived from pyrite. If siderite (iron carbonate) is present in significant quantities in the coal, a correction must be made for the iron associated with that mineral (10).

1. AYLMER, D. M., A NEW METHOD FOR THE SIMULTANEOUS DETERMINATION OF PYRITE CONTENT AND PROXIMATE ANALYSIS IN COAL AND LIGNITE, PH.D. THESIS, TEXAS A\&M UNIVERSITY, COLLEGE STATION, TEXAS, 82 P., 1983.

2. AYLMER, D. M., ROWE, M. W., "A NEW METHOD FOR THE SIMULTANEOUS DETERMINATION OF PYRITE CONTENT AND PROXIMATE ANALYSIS IN COAL," THERMOCHIMICA ACTA, 78, PP. 81-92, 1984.

3. AYLMER, D. M., ROWE, M. W., THEERMO-MAGNETO GRAVIMETRIC ANALYSIS OF PYRITE IN COAL AND LIGNITE," PROCEEDINGS OF THE TTH INTERNATIONAL CONFERENCE ON THERMAL ANALYSIS, 2, PP. 1270-1275, 1982.

4. EARNEST, C., BRENNAN, W., FYANS, R., " CHARACTERIZATION OF THE LOW TEMPERATURE ASH COMPONENT OF COALS USING MULTIPLE ATMOSPHERE DTA, TGA AND DSC TECHNIQUES," THERMOCHIMICA ACTA, 93, PP. 361-364, 1985. 
5. EARNEST, C. M., "DESCRIPTIVE OXIDATIVE PROFILES FOR PYRITE IN THE LOW TEMPERATURE ASH COMPONENT OF COALS BY DIFFERENTIAL THERMAL ANALYSIS," AMERICAN CHEMICAL SOCIETY DIVISION OF FUEL CHEMISTRY PREPRINTS, 29(1), PP. 135.143, 1984.

6. HYMAN, M., ROWE, M. W., "A NEW METHOD FOR ANALYSIS OF PYRITE IN COAL AND LIGNITE," ACS SYMPOSIUM SERIES, 169, NEW APPROACHES IN COAL CHEMISTRY, PP. $389-400,1981$.

7. HYMAN, M., ROWE, M. W., "DETERMINATION OF PYRITE IN COAL AND LIGNITE BY THERMOMAGNETIC ANALYSIS," JOURNAL OF CHEMICAL EDUCATION, 59(5), PP. 424-425, 1982.

8. MEMON, G. M., SHAN, S. M. R., "ROLE OF PARTICLE SIZE IN QUANTITATIVE DETERMINATION OF PYRITIC SULFUR IN COAL BY DIFFERENTIAL THERMAL ANALYSIS (DTA) IN DIFFERENTIAL SCANNING CALORIMETER (DSC) MODE," PROCEEDINGS OF THE SIXTH ANNUAL INTERNATIONAL PITTSBURGH COAL CONFERENCE, VOLUME 2, PP. 873 $881,1989$.

9. WARNE, S. ST. J., BLOODWORTH, A., MORGAN, D., THERMOMAGNETOMETRY AND EVOLVED GAS ANALYSIS IN THE IDENTIFICATION OF ORGANIC AND PYRITIC SULPHUR IN COAL AND OIL SHALE," THERMOCHIMICA ACTA, 93, PP. 745-748, 1985.

10. WARNE, S. ST. J., "COAL PROXIMATE ANALYSIS AND PYRITE CONTENTS BY THE TMTG METHOD. THE PROBLEM OF IRON-BEARING CARBONATES," THERMOCHIMICA ACTA, 87, PP. 353-356, 1985. 
.59 .

\section{ELECTROCHEMICAL AND OTHER METHODS}

Electrochemical methods have been applied primarilly to the characterization of pyrite in coal. These methods are similar to chemical and thermal oxidative methods, except that controlled oxidation is achieved by control of potential.

1. BRICENO, A., CHANDER, S., "AN ELECTROCHEMICAL CHARACTEFIZATIUN OF PYRITES FROM COAL AND ORE SOURCES," INTERNATIONAL JOURNAL OF MINERZAL PROCESSING, 24, PP. 73.80, 1988.

2. MISHRA, K. K., OSSEO-ASARE, K., "PHOTODISSOLUTION OF COAL PYRITE," FUEL, 66, PP. $1161 \cdot 1162,1987$.

3. OGUNSOLA, O. M., OSSEO.ASARE, K., "THE ELECTROCHEMICAL BEHAVIOR OF COAL PYRITE 1. EFFECTS OF MINERAL SOURCE AND COMPOSITION," FUEL, 65, PP. 811.815, 1986.

4. OGUNSOLA, O. M., OSSEO-ASARE, K., THE ELECTROCHEMICAL BEHAVIOR OF COAL PYRITE," FUEL, 66, PP. 467-472, 1987.

5. POPOVA, M. S., TUROVSKAYA, S. V., RYBINTSEVA, L.V., "COULOMETRIC METHOD FOR DETERMINATION OF SULFUR IN COKE," ZAVODSKAYA LABORATORIYA, 56(7), PP. 95-96, 1990. 


\section{DETERMINATION OF ELEMENTAL SULFUR}

Elemental sulfur is reported as organic sulfur when standard ASTM procedures are used for determining forms of sulfur in coal. Because the amount of elemental sulfur in most coals is very low, the inaccuracies in organic sulfur values are generally negligible. Oxidation of pyrite likely leads to the formation of elemental sulfur in coal $(4,6)$, and Cassagrande $(3)$ has reported that elemental sulfur can be incorporated into coal as organic sulfur. Recently, interest in elemental sulfur in coal has intensified because of the development of a coal cleaning process in which a significant amount of organic sulfur is removed from coal by extraction with perchloroethylene and recovered as elemental sulfur $(2,11,13,16)$.

Most methods for determining elemental sulfur in coal involve its extraction with a solvent followed by its determination by gas chromatography. Richard (14) extracted elemental sulfur from coal as well as ash particles and soll samples using cyclohexane as the solvent followed by determination by gas chromatography using an electron capture detector. Richard found levels of sulfur in coal ranging from 150 to 1000 parts per million, in ash from 9 to 200 parts per million, and in water from a pond at a coal washing plant at 38 parts per million. Richard also determined elemental sulfur in water samples exposed to coal by absorption on Amberlite XAD. 2 resin, elution with cyclohexane, and determination in the solvent by gas chromatography using an electron capture detector. Duran (9) determined elemental sulfur in coal by a similar procedure. $\mathrm{He}$ found concentratlons ranging from 300 to 1550 parts per million in aged coals and concentrations below his detection linit of 5 parts per million in pristine coals. Beyer (1) determined low levels of elemental sulfur in coal which had been subjected to biological cleaning. Several researchers have reported procedures for the direct determination of elemental sulfur in soils and sediments $(5,8)$. Chen (5) extracted marine sediments with hexane, benzene, toluene, petroleum ether, or an aniline-benzene mixture. Picogram levels of elemental sulfur were then determined in the extract by gas chromatography. Heim (12) also extracted sulfur from sediments with hexane and determined it in the extract by gas chromatography.

Athough gas chromatography is used most widely for determination of elemental sulfur, other procedures have been proposed. Feigl (10) proposed a spot test, and Skoog (15) a titrimetric procedure. Chriswell (7) isolated elemental sulfur from coalderived humic acids by a capillary-action extraction procedures using a fiberglass wick. The essentially pure sulfur isolated on the wick was determined using a Fisher analyzer. 
1. BEYER, M., EBNER, H., ASSENMACHER, H., FRIGGE, J., "ELEMENTAL SULPHUR IN MICROBIOLOGICALLY DESULFURIZED COALS," FUEL, 66, PP. 551.555, 1987.

2. BUCHANAN, D. H., WARFEL, L. C., "PERCHLOROETHYLENE EXTRACTION OF SULFUR AND SULFUR COMPOUNDS FROM COAL," AMERICAN CHEMICAL SOCIETY DIVISION OF FUEL CHEMISTRY PREPRINTS, 35(2), PP. 516.522, 1990.

3. CASAGRANDE, D. J., NG, L., "INCORPORATION OF ELEMENTAL SULFUR IN COAL AS ORGANIC SULPHUR," NATURE, 282, PP. 598-600, 1979.

4. CHATTERJEE, N. N., "FREE SULPHUR IN SOME WEATHERED TERTIARY COAL SPECIMENS OF INDIA," QUARTERLY JOURNAL OF THE GEOLOGICAL MINING METALLURGICAL SOCIETY OF INDIA, 14(1), PP. 1-7, 1942.

5. CHEN, K. Y., MOUSSAVI, M., SYCIP, A., "SOLVENT EXTRACTION OF SULFUR FROM MARINE SEDIMENT AND ITS DETERMINATION BY GAS CHROMATOGRAPHY," ENVIRONMENTAL SCIENCE AND TECHNOLOGY, 7(10), PP. 948.951, 1973.

6. CHOU, M.-I., LOFFREDO, D. M., "INFORMATION ON METHODOLOGY AND FURTHER EVIDENCE OF ELEMENTAL SULPHUR FORMATION," FUEL, 65, P. 600, 1986.

7. CHRISWELL, C. D., MARKUSZEWSKI, R., "WICK EVAPORATION - A TECHNIQUE FOR THE ISOLATION OF SOLUBLE ANALYTES FROM VOLATILE SOLVENTS," ANALYTICAL CHEMISTRY, 60, PP. 508-509, 1988.

8. CLARK, P. D., LESAGE, K. L., "QUANTITATIVE DETERMINATION OF ELEMENTAL SULFUR IN HYDROCARBONS, SOILS, AND OTHER MATERIALS," JOURNAL OF CHROMATOGRAPHIC SCIENCE, 27, PP. 259-261, 1989.

9. DURAN, J., MAHASAY, S., STACK, L., "THE OCCURRENCE OF ELEMENTAL SULPHUR IN COALS," FUEL, 65, PP. 1167.1168, 1986.

10. FEIGL, F., STARK, C., "SPOT TEST REACTION FOR DETECTION OF ELEMENTAL SULFUR," ANALYTICAL CHEMISTRY, 27, P. 1838, 1955.

11. HACKLEY, K. C., BUCHANAN, D. H., COOMBS, K., CHAVEN, C., KRUSE, C. W., "SOLVENT EXTRACTION OF ELEMENTAL SULFUR FROM COAL AND A DETERMINATION OF ITS SOURCE USING STABLE ISOTOPES," FUEL PROCESSING TECHNOLOGY, 24, PP. 431.436, 1990. 
12. HEIM, C., DEVAI, I., HARANGI, J., "GAS CHROMATOGRAPHIC METHOD FOR THE DETERMINATION OF ELEMENTAL SULPHUR IN SEDIMENTS," JOURNAL OF CHROMATOGRAPHY, 295, PP. 259-263, 1984.

13. LEE, S., KESAVAN, S. K., LEE, B. G., GHOSH, A., KULIK, C. J., "SELECTIVE REMOVAL OF ORGANIC SULFUR FROM COAL BY PERCHLOROETHYLENE EXTRACTION," FUEL SCIENCE AND TECHNOLOGY INTERNATIONAL, 7(4), PP. 443-468, 1989.

14. RICHARD, J. J., VICK, R. D., JUNK, G. A., "DETERMINATION OF ELEMENTAL SULFUR BY GAS CHROMATOGRAPHY." ENVIRONMENTAL SCIENCE AND TECHNOLOGY, 11(12), PP. 1084-1086, 1977.

15. SKOOG, D. A., BARTLETT, J. K., TITRATION OF ELEMENTAL SULFUR WITH SOLUTIONS OF SODIUM CYANIDE," ANALYTICAL CHEMISTRY, 27(3), PP. 369-371, 1955.

16. VORRES, K. S., "SULFUR SPECIES IN PERCHLOROETHYLENE AND OTHER COAL EXTRACTS," AMERICAN CHEMICAL SOCIETY DIVISION OF FUEL CHEMISTRY PREPRINTS, 35(2), PP. 523.529, 1990.

\section{DETERMINATION OF SULFIDES, SULFITES, AND OTHER REDUCED SULFUR COMPOUNDS}

In a typical coal, pyrite, organic sulfur compounds, sulfate, and elemental sulfur likely account for well over $99 \%$ of all the sulfur. However, other sulfur-containing compounds can arise during the processing of coal. A large number of procedures are applicable to determining other sulfur forms in coal or in streams resulting from coal processing. Methods developed for the determination of sulfide include spectrofluorometry (2); iodometric titration $(3,4,10,11,18)$; chemiluminescence (5); silver titrations (9); polarography 13); and by gas purging (14). Sulfite has been determined colorimetrically $(6)$; by polarography $(8,13)$; and by chemiluminescence (19). Thiosulfate may be determined by iodometric titration $(2,3,11,18)$. Bald (1) has proposed to use halopyridinium salts for the titration of thiols, and Horner (7) the determination of thioethers by oxidation with hypochlorite. Ikeda ( 9 ) has developed. an argenimetric titration for polysulfides. 
$-63-$

1. BALD, E., "ANALYTICAL UTILITY OF 2-HALOPYRIDINIUM SALTS-11: ACIDIMETRIC DETERMINATION OF THIOL GROUPS," TALANTA, 27, PP. 281-282, 1980.

2. BARK, L. S., RIXON A., "THE SPECTROFLUOROMETRIC DETERMINATION OF SULPHIDES," ANALYST, 95, PP. 786-790, 1970.

3. BETHGE, P. O., "ON THE VOLUMETRIC DETERMINATION OF HYDROGEN SULFIDE AND SOLUBLE SULFIDES," ANALYTICA CHIMICA ACTA, 9, PP. 129-139, 1953.

4. BETHGE, P. O., "ON VOLUMETRIC DETERMINATION OF HYDROGEN SULFIDE AND SOLUBLE SULFIDES," ANALYTICA CHIMICA ACTA, 10, PP. 113-116, 1954.

5. BURGUERA, J. L., TOWNSHEND, A., "DETERMINATION OF NG/ML LEVELS OF SULFIDE BY A CHEMILUMINESCENT REACTION," TALANTA, 27, PP. 309-314, 1980.

6. HINZE, W. L., ELLIOT, J., HUMPHERY, R. E., "SPECTROPHOTOMETRIC DETERMINATION OF SULFITE WITH MERCURIC THIOCYANATE AND FERRIC ION," ANALYTICAL CHEMISTRY, 44(8), PP. 1577-1513, 1972.

7. HORNER, L., GERHARD, J., "THE OXIDATION OF THIOETHERS WITH HYPOCHLORITE," PHOSPHOROUS AND SULFUR AND THE RELATED ELEMENTS," 22(1), PP. 5-11, 1985.

8. HUMPHREY, R. E., SHARP, S. W., "POLAROGRAPHIC DETERMINATION OF CHLORIDE, CYANIDE, FLUORIDE, SULFATE, AND SIJLFITE IONS BY AN AMPLIFICATION PROCEDURE EMPLOYING METAL IODATES," ANALYTICAL CHEMISTRY, 48(1), PP. 222-223, 1976.

9. IKEDA, S., SATAKE, H., HISANO, T., TERAZAWA, T., "POTENTIOMETRIC ARGENTIMETRIC METHOD FOR THE SUCCESSIVE TITRATION OF SULPHIDE AND POLYSULFIDES DISSOLVED IN POLYSULPHIDE SOLUTIONS," TALANTA, 19, PP. 1650-1654, 1972.

10. KILROY, W. P., "ANALYSIS OF MIXTURES OF SULPHIDES, THIOSULPHATE, DITHIONATE, AND SULPHITE," TALANTA, 30(6), PP. 419-422, 1983.

11. KILROY, W. P., THE IODOMETRIC DETERMINATION OF DITHIONATE, THIOSULPHATE, AND SULPHITE IN THE PRESENCE OF ALKALI AND/OR CYANIDE," TALANTA, 27(4), PP. 343-347, 1980.

12. MAKHIJA, R., HITCHEN, A., "DETERMINATION OF POLYTHIONATES AND THIOSULPHATES IN MINING EFFLUENTS AND MILL CIRCUIT SOLUTIONS," TALANTA, 25, PP. 79-84, 1978. 
13. RENARD, J. J., KUBES, G., BOLKER, H. I., "POLAROGRAPHIC DETERMINATION OF SULFUR COMPOUNDS IN PULPING LIQUORS," ANALYTICAL CHEMISTRY, 47(8), PP. 1347-1351, 1975.

14. RICHARDSON, R. G., CHRISWELL, C. D., MARKUSZEWSKI, R., "DETERMINATION OF SULFIDE IN SPENT CAUSTIC SOLUTIONS ARISING FROM THE CHEMICAL CLEANING OF COAL," FUEL PROCESSING TECHNOLOGY, 22(198), PP. 217-226, 1989.

15. SORBO, B. O., "A COLORIMETRIC METHOD FOR THE DETERMINATION OF THIOSULFATE," BIOCHIMICA BIOPHYSICA ACTA, 23, PP. 412-416, 1957.

16. STAHL, J. W., JORDAN, J., "THERMOMETRIC TITRATION OF POLYSULFIDES," ANALYTICAL CHEMISTRY, 59, PP. 1222-1225, 1987.

17. STARKEY, R. L., "PRODUCTS OF THE OXIDATION OF THIOSULFATE BY BACTERIA IN MINERAL MEDIA," JOURNAL OF GENERAL PHYSIOLOGY, 18, PP. 325-348, 1935.

18. STEPHENSON, M. D., WHEELOCK, T. D., MARKUSZEWSKI, R., "SULFUR SPECIES LEACHED FROM PYRITE DURING OXIDATIVE DESULFURIZATION OF COAL IN ALKALINE SOLUTIONS," PROCEEDINGS OF THE 1983 INTERNATIONAL CONFERENCE ON COAL SCIENCE, PITTSBURGH, PENNSYLVANIA, PP. 252-255, AUG. 15-19, 1983.

19. TAKEUCHI, K., IBUSUKI, T., "DETERMINATION OF TRACES OF HYDROGEN SULFITE BY CHEMILUMINESCENCE WITH CERIUM(IV) SULFATE AS THE REAGENT," ANALYTICA CHIMICA ACTA, 174, PP. 359-363, 1985.

20. THOM, G. C., WATERS, P. F., HADERMAN, A. F., "FORMATION AND DECOMPOSITION OF THIOSULFATE IN THE FERROUS SULFIDE-SULFUR DIOXIDE REACTION," INORGANIC CHEMISTRY, 17(6), PP. 1693-1696, 1978.

\section{STANDARDS FOR USE IN COAL ANALYSES}

In the United States, the National Institute for Standards and Technology (NIST) formerly the National Bureau of Standards (NBS) is the primary source of certified standards for use in evaluating methods for determining sulfur in coal. Gills (2) reported on the procedures used by the NIST to certify standard reference materials. Griepink (3) has reported on the certification of six coals by the European 
Community. Beyond these certified standards, other workers have described procedures and materials for use as standards for specific determinations. Castle and others (1) described procedures for synthesizing compounds which could be used as standards during the determination of compounds isolated from coal. Irgum (4) addressed the problem of the instability of sulfite standards by proposing a stable surrogate standard. Luck (6) prepared and analyzed synthetic pyrite, which could be used as a standard. Moore (7) demonstrated that inorganic sulfate was usable as a standard sulfur for certain determinations.

1. CASTLE, R. N., TEDJAMULIA, M. L., TOMINAGA, Y., PRATAP, R., SUGIURA, M., KUDO, H., LEE, M. L., IWAO, M., THOMPSON, R. D., MARTIN, G. E., GRAMPLE, R. T., JR., MUSMAR, M. J., WILLCOTT, M. R., SMITH, S. L., LAYTON, W. J., HURD, R. E., JOHNSON, L. F., THE SYNTHESIS AND PROPERTIES OF POLYCYCLIC AROMATIC THIOPHENES AND RELATED HETEROCYCLES OCCURRING IN COAL-DERIVED PRODUCTS," LECTURES ON HETEROCYCLICAL CHEMISTRY, 1, PP. 1-52, 1984.

2. GILLS, T., "METHODS AND PROCEDURES USED AT THE NATIONAL BUREAU OF STANDARDS TO CERTIFY SULFUR IN COAL SRM'S FOR SULFUR CONTENT, CALORIFIC VALUE, AND ASH CONTENT," STANDARD REFERENCE MATERIALU.S. DEPT. OF COMMERCENATIONAL BUREAU OF STANDARDS SERIAL PUBLICATION, NO. 260-294, DEC. 1984.

3. GRIEPINK, B., MAIER, E. A., WILKINSON, H., "THE CERTIFICATION OF THE CONTENTS (MASS FRACTIONS) OF SULFUR IN SIX COALS," COMM, EUR. COMMUNITIES [REP]EUR, 12646, 39 P., 1990.

4. IRGUM, K., "STABILIZED GRAVIMETRIC STANDARD FOR SULFITES AND SULFUR DIOXIDE," ANALYTICAL CHEMISTRY, 57, PP. 1496-1498, 1985.

5. JAYANTY, R. K. M., SOKOL, C. K., ESTER, E. D., FUERT, R. G., LOGAN, T. J., MIDGETT, M. R., "DEVELOPMENT OF NEW AUDIT MATERIALS FOR DETERMINING TOTAL SULFUR IN COAL," JOURNAL OF COAL QUALITY, 7(4), PP. 137-141, 1988.

6. LUCK, J., HARTMANN, A., FIECHTER, S., "STOICHIOMETRY AND IMPURITY CONCENTRATIONS IN SYNTHETICALLY GROWN IRON PYRITE CRYSTALS AND THEIR CONSTITUENTS," FRESENIUS S. ANAL. CHEM., 334(5), PP. 441-446, 1989. 
7. MOORE, P. J., "SULFUR IN COAL ANALYSIS USING INORGANIC CALIBRATION STANDARDS," PROCEEDIN3SS OF THE EIGHTH INTERNATIONAL COAL TESTING CONFERENCE, PP. 17-22, 1990.

\section{REVIEWS AND COMMENTARIES ON SULFUR METHODS}

1. ANGELOVA, G. K., SYSLEOV, K. I., "ABOUT THE POSSIBLE FORMS OF ORGANIC SULFUR IN COAL," IZV. AKAD. NAUK SSSR, METALL. TOPL., (RUSSIAN METALLURGY AND FUELS), 5, PP. 153-158, 1959.

2. BAN, Y., SUGAWARA, T., FURUYA, K., GOHSHI, Y-I., "COMPARISON OF CHEMICAL, STATE, AND FORM ANALYSES OF SULFUR IN COAL," BUNSEKI KAGAKU, 34(5), PP. 238-242, 1985.

3. BARANSKII, A. D., RODIONOVA, L. E., FISENKO, N. N, AND TODAVCHICH, N. I., "ORGANIC SULFUR IN BITUMINOUS COALS," KHIMIYA TVERDOGO TOPLIVA, 1, PP. 50-56, 1973.

4. CHAKROBARTTY, S., IACCHELLI, A., "THE DILEMMA OF ESTIMATING FORMS OF SULFUR IN LOW-RANK COALS," CANADIAN JOURNAL OF CHEMISTRY, 64 (5), PP. 861-864, 1986.

5. CHATTERJEE, N. N., "SULPHUR IN COAL," PROCEEDINGS INDIAN NATIONAL SCIENCE ACADEMY, 6(3), PP. 523-534, 1940.

6. CHEN, P., CHEN, W., "STUDY ON THE DISTRIBUTION CHARACTERISTICS OF SULPHUR IN CHINESE COALS," FUEL, 65, PP. 1305-1309, 1986.

7. CHOU, C. L., "GEOCHEMISTRY OF SULFUR IN COAL," GEOCHEMISTRY OF SULFUR IN FOSSIL FUELS, ACS SYMPOSIUM SERIES NO. 429, W. L. ORR AND C. M. WHITE, EDS., PP. 30-52, AMERICAN CHEMICAL SOCIETY, WASHINGTON, D. C., 1990.

8. CHOWDHURY, J. K., DATTA, P. B., GHOSH, S. R., "INVESTIGATION ON HIGH SULPHUR ASSAM COALS: PART 1-DESULPHURIZATION, PART 2-SULPHUR COMPOUNDS IN COAL," JOURNAL OF SCIENTIFIC INDUSTRY, 118, PP. 146-152, 1952.

9. DACEY, P. W., COLBOURN, P., "AN ASSESSMENT OF METHODS FOR THE DETERMINATION OF IRON PYRITES IN COAL MINE SPOIL," RECLAMATION REVIEW, 2, PP. 113-121, 1979. 
10. EDWARDS, A., DAYBELL, G., PRINGLE, W., "AN INVESTIGATION INTO METHODS FOR THE DETERMINATION OF FORMS OF SULPHUR IN COAL," FUEL, 37, PP. 47-61, 1958.

11. FRIEDMAN, S., "SULFUR ANALYSES OF COAL - A CRITICAL EVALUATION," PROCEEDINGS: FIRST INTERNATIONAL SYMPOSIUM ON THE BIOLOGICAL PROCESSING OF COAL, (EPRI GS 6970), PP. 1-3 - 1-14, 1990.

12. GIVEN, P. H., "THE CHEMISTRY OF SULFUR IN COAL," THE BRITISH COAL UTILIZATION RESEARCH ASSOCIATION, MONTHLY BULLETIN, REVIEW NO. 204, 25(5), PP. 165-179, 1961.

13. HAMERSMA, J. W., KRAFT, M. L., COAL SULFUR MEASUREMENTS, TRW DEFENSE AND SPACE SYSTEMS GROUP, REDONDO BEACH, CALIFORNIA, CONTRACT NO. 68.02-2165, EPA-600/7-79-150, JULY, 1979.

14. HEILPERN, S., SWEICA, G., "ACCURACY OF STANDARDIZED METHODS FOR DETERMINATION OF VARIOUS FORMS OF SULFUR IN COAL AND COKE," KOKS-SMOLAGAZ, 34(2), PP. 27-31, 1989.

15. HEUNISCH, G. W., "ELUSIVE PYRITE SULFUR," JOURNAL OF COAL QUALITY, 3(3), PP. 6-7, 1984.

16. KARR, C., JR., ED., ANALYTICAL METHODS FOR COAL AND COAL PRODUCTS, VOLUMES I, II, III, ACADEMIC PRESS, NEW YORK, 1978.

17. MARKUSZEWSKI, R., "METHODS FOR SULFUR IN COAL," PROCEEDINGS OF THEE THIRD INTERNATIONAL COAL TESTING CONFERENCE, LEXINGTON, KENTUCKY, PP. 14-16, OCT. 24-26, 1983.

18. MARKUSZEWSKI, R., "SOME THOUGHTS ON THE DIFFICULTIES IN THE ANALYSIS OF SULFUR FORMS IN COAL," JOURNAL OF COAL QUALITY, 7(1), PP. 1-4, 1988.

19. MEYER, B., SULFUR AND THE ENVIRONMENT, ELSEVIER, AMSTERDAM, 1977.

20. NUSS, E. R., "ANALYTICAL METHODS TO CHARACTERIZE AND QUANTIFY SULFUR IN COAL," DOEJORVO0033-T360, NTIS NO. DE 88002401, 36 P., 1987.

21. ORR, W. L., WHITE, C. M., EDS., GEOCHEMISTRY OF SULFUR IN FOSSIL FUELS, ACS SYMPOSIUM SERIES NO. 429, AMERICAN CHEMICAL SOCIETY, WASHINGTON, D. C., 1990. 
22. REES, O. W., "CHEMISTRY, USES AND LIMITATIONS OF COAL ANALYSES," REPORT OF INVESTIGATIONS, NO. 220, ILLINOIS STATE GEOLOGICAL SURVEY, URBANA, ILLINOIS, 1966.

23. STANEK, J., BURYAN, P., MACAK, J., "DETERMINATION OF THE DISTRIBUTION OF ORGANIC FUNCTIONAL GROUPS OF SULFUR IN COAL," SBORNIK WYSOKE SKOLY CHEMICKO-TECHNOLOGICKE V PRAZE, D54, PP. 201-218, 1986.

24. STANTON, R., RENTON, J., "ORGANIC AND PYRITIC SULFUR IN COAL: POTENTIAL ERRORS IN DETERMINATION," WEST VIRGINIA GEOLOGICAL AND ECONOMIC SURVEY, C22, 1981.

25. SUHR, N., GIVEN, P. H., "RELIABILITY OF DETERMINATIONS OF PYRITIC IRON IN COALS USING STANDARD PROCEDURES," FUEL, 60(6), PP. 541-542, 1981.

26. WILIAMS, W. J., "SULFATE," HANDBOOK OF ANION DETERMINATION, BUTTERWORTHS: LONDON, ENGLAND, PP. 529-567, 1979. 


\section{DISTRIBUTION LIST}

Ames Laboratory

(6)

Technical Information Office

lowa State University

$2190 \& \mathrm{~L}$

Ames, lowa 50011-3020

Chicago Field Office

Patent Counsel

(1)

9800 South Cass Avenue

Argonne, Illinois 60439

Director

(1)

ISURF

315 Beardshear

lowa State University

Ames, lowa 50011-3020

Office of Scientific and Technical Information

(30)

U.S. Department of Energy

P. O. Box 62

Oak Ridge, Tennessee 37830

Morgantown Energy Technology Center

(2)

(Library)

(P. Weiber)

Pittsburgh Energy Technology Center

(3)

(R. Hucko)

(R. Read)

(M. Nowak)

US DOE - Washington

(3)

(H. Feibus)

(R. Pennington)

(J. Siegel) 
Fossil Energy Program Office

Ames Laboratory

280 Metals Development Building

lowa State University

Ames, lowa 50011

Authors

C. Chriswell

G. Norton

S. Akhtar

W. Straszheim

R. Markuszewski

Fossil Energy Principal Investigators

(7)

(R. Brown)

(W. Buttermore)

(M. R. Dawson)

(C. Kilgour)

(B. Slomka)

(J. Verkade)

(T. Wheelock)

Electric Power Research Institute

(5)

(W. Weber)

(R. Wolk)

(C. Kulik)

(J. Maulbetsch)

(S. Yunker)

Fossil Fuels Sciences Group

(H. Lebowitz) 

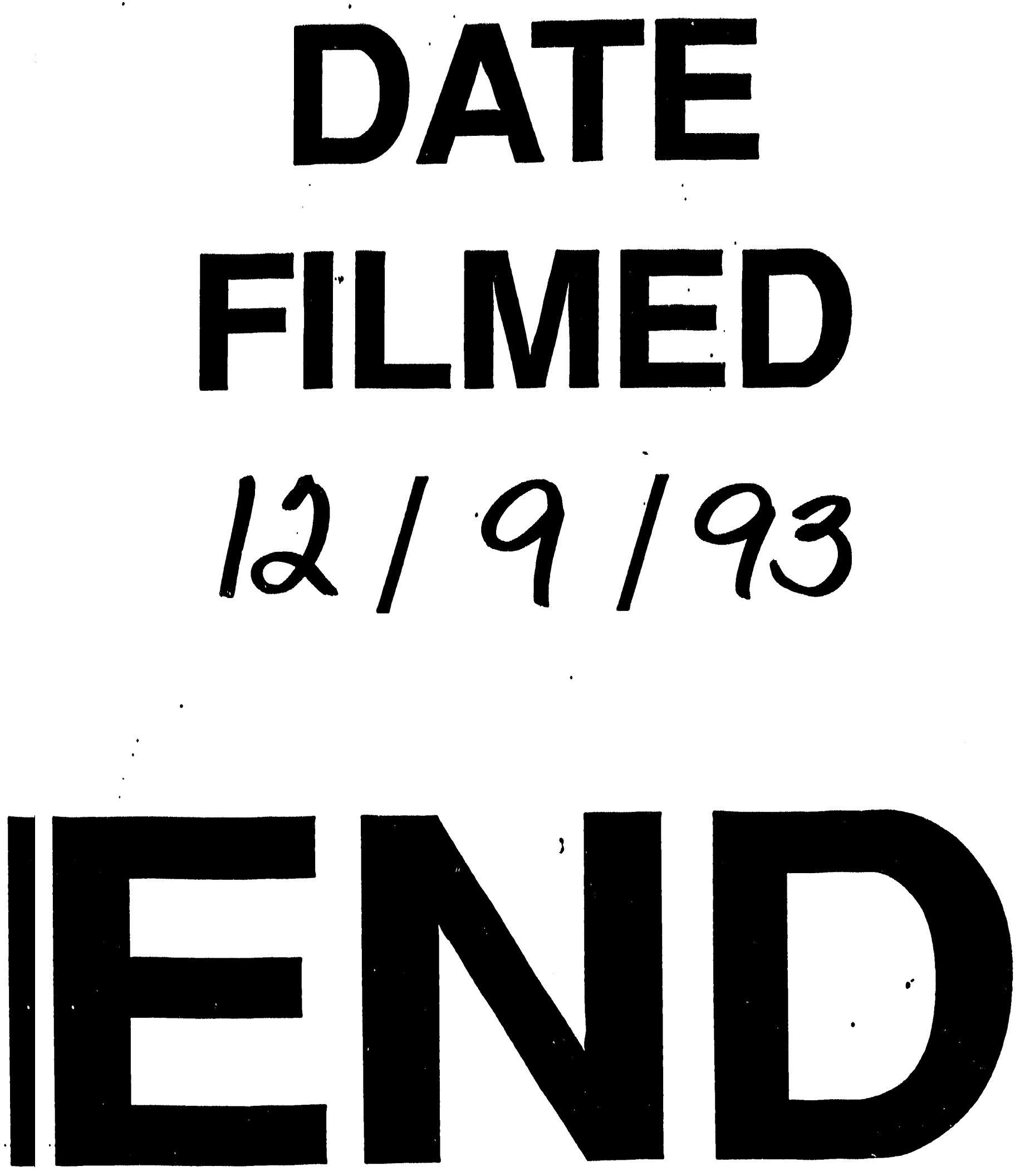
